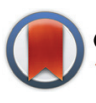

CrossMark \& click for updates

Cite this: Dalton Trans., 2016, 45, 4633

Received 21st October 2015, Accepted 23rd January 2016 DOI: 10.1039/c5dt04132e

www.rsc.org/dalton

\section{DNA binding properties, histidine interaction and cytotoxicity studies of water soluble ruthenium(II) terpyridine complexes $\dagger$}

\author{
Dejan Lazić, ${ }^{a}$ Aleksandar Arsenijević, ${ }^{a}$ Ralph Puchta, ${ }^{b, c}$ Živadin D. Bugarčićd and \\ Ana Rilak*d
}

In this study, two representatives of previously synthesized ruthenium(॥) terpyridine complexes, i.e., $[\mathrm{Ru}(\mathrm{Cl}$-tpy)(en) $\mathrm{Cl}][\mathrm{Cl}](\mathbf{1})$ and $[\mathrm{Ru}(\mathrm{Cl}$-tpy)(dach)Cl][Cl] (2), were chosen and a detailed study of the kinetic parameters of their reactivity toward L-histidine (L-His), using the UV-Vis and ${ }^{1} \mathrm{H}$ NMR techniques, was developed. The inner molecular rearrangement from N3-coordinated L-His to the N1 bound isomer, observable in the NMR data, was corroborated by DFT calculations favoring N1 coordination by nearly $4 \mathrm{kcal} \mathrm{mol}{ }^{-1}$. These two ruthenium(॥) terpyridine complexes were investigated for their interactions with DNA employing UV-Vis spectroscopy, DNA viscosity measurements and fluorescence quenching measurements. The high binding constants obtained in the DNA binding studies $\left(K_{\mathrm{b}}=10^{4}-10^{5} \mathrm{M}^{-1}\right)$ suggest a strong binding of the complexes to calf thymus (CT) DNA. Competitive studies with ethidium bromide (EB) showed that the complexes can displace DNA-bound EB, suggesting strong competition with EB $\left(K_{\mathrm{sv}}=1.5-2.5 \times 10^{4} \mathrm{M}^{-1}\right)$. In fact, the results indicate that these complexes can bind to DNA covalently and non-covalently. In order to gain insight of the behavior of a neutral compound, besides the four previously synthesized cationic complexes $[\mathrm{Ru}(\mathrm{Cl}$-tpy)(en) $\mathrm{Cl}][\mathrm{Cl}](\mathbf{1}),[\mathrm{Ru}(\mathrm{Cl}$-tpy)(dach) Cl][Cl] (2), $[\mathrm{Ru}$ $\left(\mathrm{Cl}\right.$-tpy)(bpy)Cl][Cl] (3) and $\left[\mathrm{Ru}(\mathrm{tpy}) \mathrm{Cl}_{3}\right](\mathbf{P 2})$, a new complex, $[\mathrm{Ru}(\mathrm{Cl}$-tpy)(pic) $\mathrm{Cl}](\mathbf{4})$, was used in the biological studies. Their cytotoxicity was investigated against three different tumor cell lines, i.e., A549 (human lung carcinoma cell line), HCT116 (human colon carcinoma cell line), and CT26 (mouse colon carcinoma cell line), by the MTT assay. Complexes 1 and 2 showed higher activity than complexes 3, 4 and $\mathbf{P} \mathbf{2}$ against all the selected cell lines. The results on in vitro anticancer activity confirmed that only compounds that hydrolyze the monodentate ligand at a reasonable rate show moderate activity, provided that the chelate ligand is a hydrogen bond donor.

\section{Introduction}

Cisplatin is one of the most widely used anticancer drugs but due to its serious side effects, clinical applications of cisplatin are limited. ${ }^{1-3}$ In the search for anticancer agents containing metals other than platinum, ruthenium compounds proved to be the most promising ones. ${ }^{4-7}$ The advantage of ruthenium-

\footnotetext{
${ }^{a}$ Faculty of Medicine, Centre for Molecular Medicine and Stem Cell Research, University of Kragujevac, Svetozara Markovića 69, 34000 Kragujevac, Serbia ${ }^{b}$ Institute for Inorganic Chemistry, Department of Chemistry and Pharmacy, University of Erlangen-Nürnberg, Egerlandstraße 1, 91058 Erlangen, Germany ${ }^{c}$ Computer Chemistry Center, Department of Chemistry and Pharmacy, University of Erlangen-Nürnberg, Nägelsbachstraße 25, 91052 Erlangen, Germany

${ }^{d}$ Department of Chemistry, Faculty of Science, University of Kragujevac, Radoja Domanovića 12, P. O. Box 60, 34000 Kragujevac, Serbia. E-mail: anarilak@kg.ac.rs; Fax: +381(0)34335040; Tel: +381 (0)34300262

$\dagger$ Electronic supplementary information (ESI) available. See DOI: 10.1039/ c5dt04132e
}

based drugs could derive from their reduced toxicity, good selectivity for tumors, inhibition of antimetastatic progression and antiangiogenic properties. ${ }^{8-10}$ This is believed to be due to the ability of ruthenium to mimic iron in binding to biomolecules, such as human serum albumin and transferrin. As cancer cells overexpress transferring receptors, to satisfy their increased demand for iron, ruthenium-based drugs may be delivered more efficiently to cancer cells. ${ }^{11,12}$ Two promising ruthenium anticancer agents, $[$ IndH $]\left[\right.$ trans $-\left[\mathrm{RuCl}_{4}(\text { Ind })_{2}\right]$ (Ind = indazole, $\mathrm{KP} 1019)^{13}$ and $[\mathrm{ImH}]\left[\right.$ trans- $\left.^{13} \mathrm{RuCl}_{4}(\mathrm{Im})(\mathrm{DMSO}-\mathrm{S})\right]$ (Im = imidazole, NAMI-A), ${ }^{14}$ have successfully entered clinical trials as promising anticancer drugs..$^{6,8,15,16}$ More recently, half sandwich organometallic $\mathrm{Ru}(\mathrm{II})$ compounds of the general formula $\left[\mathrm{Ru}\left(\eta^{6}\right.\right.$-arene $\left.)(\mathrm{N}-\mathrm{N}) \mathrm{X}\right]\left[\mathrm{PF}_{6}\right]$ have been extensively investigated by Sadler and coworkers. They were found to possess promising activity both in vitro and in vivo. ${ }^{17-22}$

In the last few decades, $\mathrm{Ru}(\mathrm{II})$ polypyridyl complexes of the type mer-[Ru(tpy)(N-N)Cl$]^{+}$containing different $\mathrm{N}$-donor 
chelating ligands $(\mathrm{N}-\mathrm{N})$, such as bpy, ${ }^{23,24}$ 1,10-phenanthroline (phen), ${ }^{23-25}$ 3,4,7,8-tetramethyl-1,10-phenanthroline (tmephen), ${ }^{26}$ dipyrido(3,2-a:2', $\left.3^{\prime}-c\right]$ phenazine $\quad(\mathrm{dppz}),{ }^{24,26} \quad N, N, N^{\prime}, N^{\prime}$-tetramethylethylenediamine (tmen), ${ }^{23,26} 2,2^{\prime}$-azobispyridine (apy), ${ }^{27}$ azpy, ${ }^{28}$ have been prepared and studied for their DNA binding ability. It was found that most of the $\mathrm{Ru}(\mathrm{II})$-tpy complexes are capable of binding covalently to DNA (mainly at guanine residues) forming monofunctional adducts and DNA replication was stopped by some of them. ${ }^{25,29}$

Recently, we developed a series of new ruthenium polypyridyl complexes of the general formula $\operatorname{mer}-\left[\mathrm{Ru}\left(\mathrm{L}_{3}\right)(\mathrm{N}-\mathrm{N}) \mathrm{X}\right][\mathrm{Y}]_{n}$ in which $\mathrm{L}_{3}$ is either tpy or Cl-tpy (4'-chloro-2,2':6',2"-terpyridine), $\mathrm{X}=\mathrm{Cl}$ or DMSO-S, N-N = en, dach or bpy, $\mathrm{Y}=\mathrm{Cl}, \mathrm{PF}_{6}$ or $\mathrm{CF}_{3} \mathrm{SO}_{3}$, and $n=1$ or 2 , depending on the nature of $\mathrm{X}^{30}$ Since all these compounds were cationic, with the aim of evaluating the behavior of a neutral complex, the synthesis and characterization of a $\mathrm{Ru}(\mathrm{II})-$ tpy complex with the anionic $\mathrm{N}-\mathrm{O}$ chelating ligand picolinate (4) (Fig. 1) are reported herein. Previous studies on the three $\mathrm{Ru}(\mathrm{II})$ polypyridyl complexes, i.e., $[\mathrm{Ru}(\mathrm{Cl}-$ tpy)(en)Cl $][\mathrm{Cl}]$ (1), [Ru(Cl-tpy)(dach)Cl $][\mathrm{Cl}]$ (2) and [Ru(Cl-tpy) (bpy)Cl][Cl] (3) (Fig. 1), demonstrated that after the hydrolysis of the Cl ligand, they were capable of interacting with guanine derivatives (i.e., 9-methylguanine (9MeG) or guanosine-5'- monophosphate (5'-GMP)) through the N7, forming monofunctional adducts with rates and extents that depended strongly on the nature of the chelating ligand. ${ }^{30}$

Despite the fact that ruthenium complexes can bind to DNA, ${ }^{29}$ recent research seems to favor the hypothesis that their interactions with proteins specific for processes of cancer development are crucial. ${ }^{5}$ Therefore, it is quite possible that ruthenium complexes have multiple targets, and a combination of their actions contributes to their observed beneficial properties. It is well-recognized that ruthenium complexes bind to surface-accessible histidyl imidazoles of albumin and transferrin after their intravenous administration. ${ }^{31-34}$ Such interactions could be responsible for drug inactivation (related to resistance) or activation (e.g., in the case of prodrugs) and drug delivery. Histidine forms a crucial part of many biological systems through binding to heme proteins and is a part of the catalytic sites in certain enzymes. ${ }^{35,36}$ Thus, as histidine has wide applications in biological systems, it would be of great interest to study this amino acid and to understand the manner in which it binds. With this in mind, the kinetics of histidine interaction form part of the present study. UV-Vis and NMR spectroscopic experiments and density functional theory (DFT) calculations were conducted to elucidate the

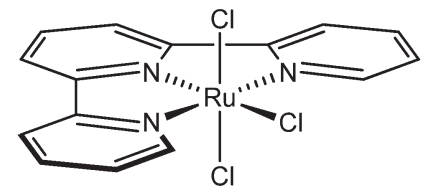

P2

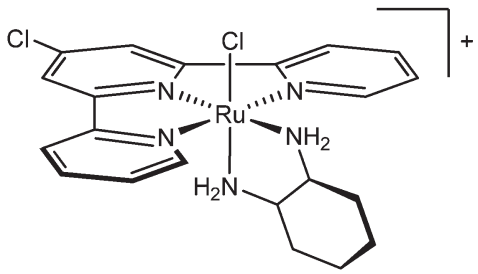

2

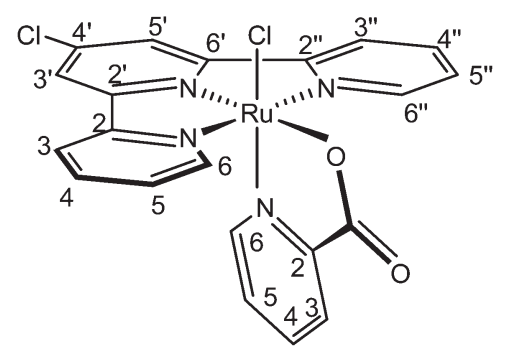

4

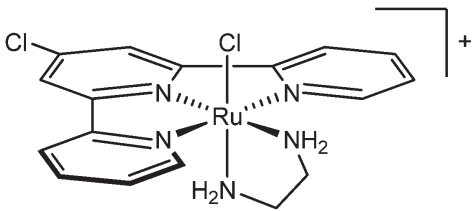

1

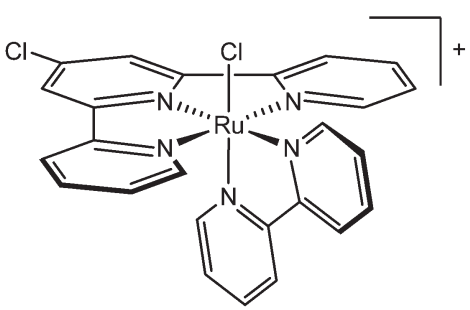

3

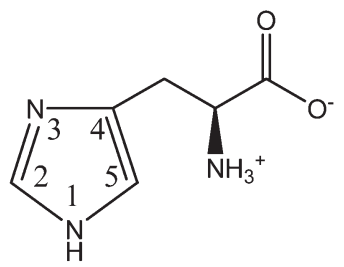

L-His

Fig. 1 Structures of the investigated complexes with the numbering scheme of the pic ligand and those of the L-His used for the NMR characterization. 
affinity of the terpyridine complexes toward the amino acid L-histidine. Focus was also directed to the interaction of the Ru(II)-tpy complexes with calf-thymus (CT) DNA and the ability of the complexes to displace ethidium bromide (EB) from the EB-DNA complex in order to clarify the existence of a potential intercalation of the $\mathrm{Ru}$ (II) complexes to CT DNA in competition with the classical DNA-intercalator EB. The results obtained in the DNA binding studies prompted an in vitro cytotoxicity evaluation of the ruthenium complexes on three tumor cell lines, A549 (human lung carcinoma cell line), HCT116 (human colon carcinoma cell line), and CT26 (mouse colon carcinoma cell line) using the MTT assay. Furthermore, in order to provide precious indications for future synthetic purposes, determining whether changes in the nature of the chelating bidentate ligand would influence the cytotoxic activity of these ruthenium(II) polypyridyl complexes was of interest.

\section{Results and discussion}

\section{Synthesis and characterization of the complex}

As mentioned above, in contrast to the cationic compounds 1-3, ${ }^{30}$ a new neutral complex was synthesized and characterized in order to examine its behavior. Treatment of the neutral
$\mathrm{Ru}(\mathrm{III})$ precursor $m e r-\left[\mathrm{Ru}(\mathrm{Cl}-\mathrm{tpy}) \mathrm{Cl}_{3}\right]$ (P1) with the anionic $\mathrm{N}-\mathrm{O}$ chelating ligand, pic, in the presence of $\mathrm{Et}_{3} \mathrm{~N}$ as a reductant and an excess of $\mathrm{LiCl}$, needed for preventing $\mathrm{Cl}^{-}$dissociation from the final product and necessary for its precipitation, afforded the neutral $\mathrm{Ru}(\mathrm{II})$ complex $[\mathrm{Ru}(\mathrm{Cl}-\mathrm{tpy})(\mathrm{pic}) \mathrm{Cl}]$ (4) in fair to very good yields (Scheme 1).

The new complex was characterized using $1 \mathrm{D}\left({ }^{1} \mathrm{H},{ }^{13} \mathrm{C}\right)$ and 2D $\left({ }^{1} \mathrm{H}-{ }^{1} \mathrm{H}\right.$ COSY, ${ }^{1} \mathrm{H}_{-}{ }^{13} \mathrm{C}$ HSQC and ${ }^{1} \mathrm{H}^{-13} \mathrm{C}$ HMBC) NMR, IR and UV spectroscopy and elemental analysis.

Although in theory two isomers of $\mathbf{4}$ are possible, i.e., one in which the $\mathrm{Cl}^{-}$is trans to the $\mathrm{N}_{\text {pyridine }}$ of pic ${ }^{-}$and the other in which the $\mathrm{Cl}^{-}$is trans to the $\mathrm{O}_{\text {carboxyl }}$, the ${ }^{1} \mathrm{H}$ NMR spectrum, in either $\mathrm{CD}_{3} \mathrm{CN}$ (Fig. 2) or a mixture of acetone- $d_{6} / \mathrm{D}_{2} \mathrm{O}$ (Fig. $\mathrm{S} 1 \dagger$ ), revealed the existence of only one species. The remarkable upfield shifts of the $\mathrm{H} 5_{\text {pic }}$ and $\mathrm{H} 6_{\text {pic }}$ resonances ( $\delta=6.79$ and 6.76 , respectively), which are influenced by the shielding cone of Cl-tpy, are indicative that the pyridyl ring of pic is under the plane of the Cl-tpy, viz. trans to $\mathrm{Cl}^{-}$(Fig. 2). Accordingly, the protons of Cl-tpy, and in particular H6/H6", are not affected by the shielding cone of pic, as observed in the case of bpy, ${ }^{30}$ and thus, they resonate in the typical region for tpy and display the usual pattern.

The solid state IR spectrum of complex $\mathbf{4}$ showed typical bands of the terpyridine ligand, the most characteristic of which is the strong band in the region $1594-1616 \mathrm{~cm}^{-1}$
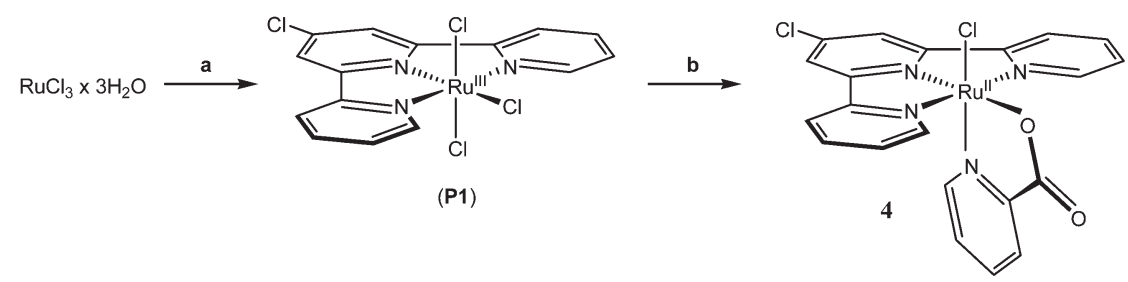

Scheme 1 Synthetic pathway for the preparation of complex 4. Reagents and conditions: (a) $\mathrm{Cl}$-tpy (0.9 eq.), EtOH, reflux; (b) pic (1.2 eq.), ethanol : $\mathrm{H}_{2} \mathrm{O}$ (3 : 1), Et ${ }_{3} \mathrm{~N}$ (3.0 eq.), $\mathrm{LiCl}(10.0$ eq.), reflux.

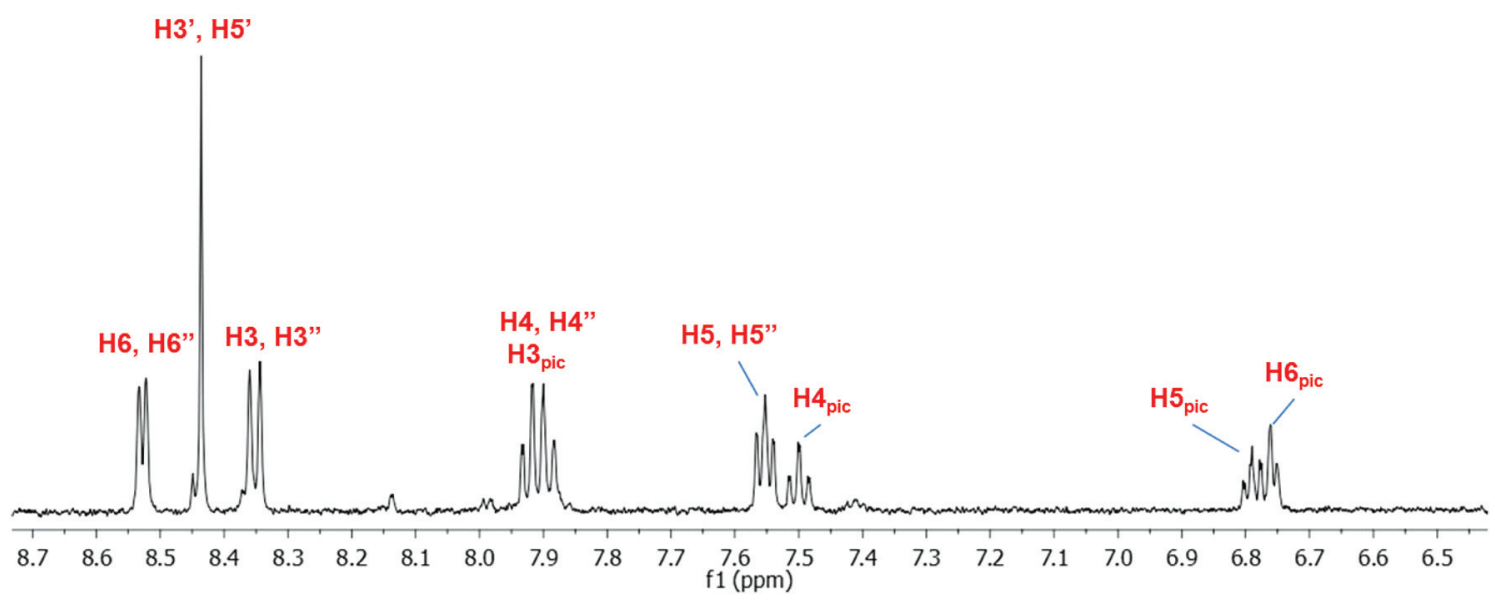

Fig. $2{ }^{1} \mathrm{H}$ NMR spectrum of the $\left[\mathrm{Ru}(\mathrm{Cl}\right.$-tpy)(pic) $\mathrm{Cl}]$ complex in $\mathrm{CD}_{3} \mathrm{CN}$. 
assigned to $\nu(\mathrm{C}=\mathrm{N})$ stretching. ${ }^{37,38}$ There were two additional bands at 1630 and $1343 \mathrm{~cm}^{-1}$, attributed to the asymmetric and symmetric carboxylate stretching modes, respectively.

The electronic absorption spectrum of complex 4 (Fig. S2 $\dagger$ ) exhibited several intense bands in the UV region $(200<\lambda<$ $330 \mathrm{~nm})$, attributed to intra-ligand $\left(\pi \rightarrow \pi^{*}\right)$ charge transitions, and a broad intense band in the visible region attributed to metal to ligand $\mathrm{d} \pi(\mathrm{Ru}) \rightarrow \pi^{*}$ (polypyridyl) charge transfer (MLCT) transitions. ${ }^{37-39}$

In contrast to the previously synthesized ruthenium polypyridyl complexes $\mathbf{1}$ and $\mathbf{2}$, the $\mathrm{Cl}^{-}$ligand of which was observed to be rapidly hydrolyzed upon dissolution in water, ${ }^{30}$ the picolinate complex $\mathbf{4}$ was very stable and inert since no release of the $\mathrm{Cl}^{-}$ligand was detected even after several hours of observation (see Fig. S1†). Due to its poor solubility and inertness in aqueous solution, this compound was not further examined, except for its biological activity.

\section{Interaction with the amino acid ${ }_{L}$-histidine}

UV-Vis kinetic studies. Although much less studied than metallodrug-DNA interactions, the interactions of metallodrugs with protein targets deserve more attention, especially since such studies would not only shed light on the mechanisms of action, but also help to identify new targets for drug therapy. ${ }^{11,16,40}$ The efficiency of a drug may be affected by the degree to which it binds to proteins within blood plasma. Common blood proteins to which drugs bind are human serum albumin (HSA) and transferrin. In particular, since histidine residues on the surface of albumin and transferrin were characterized as the binding sites for both $\mathrm{Ru}(\mathrm{II})$ and $\mathrm{Ru}(\mathrm{III}),{ }^{31-34,41,42}$ the kinetics of histidine interaction with two ruthenium(II) terpyridine complexes were studied in the present work.

The substitution kinetics of $\mathrm{Cl}^{-}$with L-His in complexes 1 and 2 were investigated spectrophotometrically (Fig. S3†) by following the changes in absorbance at selected wavelengths, corresponding to the maximum change in the absorption (Fig. S4, $\uparrow$ difference spectra), as a function of time. All kinetic experiments were performed under pseudo-first-order conditions with respect to the nucleophile in order to force the reactions to go to completion. To suppress the spontaneous hydrolysis of chloride from the $\mathrm{Ru}(\mathrm{II})$ complexes, all reactions were studied in the presence of $30 \mathrm{mM} \mathrm{NaCl}$. This value was determined prior to the kinetic measurements to be the minimum chloride concentration for which no spectral changes were observed (Fig. S5 $\dagger$ ).

The substitution reactions of complexes 1 and 2 with L-His could be represented by eqn (1):

$$
\begin{aligned}
{[\mathrm{Ru}(\mathrm{Cl}-\mathrm{tpy})(\mathrm{N}-\mathrm{N}) \mathrm{Cl}]^{+}+\mathrm{L}-\mathrm{His} \rightleftharpoons } & {[\mathrm{Ru}(\mathrm{Cl}-\mathrm{tpy})(\mathrm{N}-\mathrm{N})(\mathrm{L}-\mathrm{His})]^{2+} } \\
& +\mathrm{Cl}^{-}
\end{aligned}
$$

where $\mathrm{N}-\mathrm{N}=$ en or dach.

Here, $k_{2}$ is the second-order rate constant for the forward reaction, involving the direct nucleophilic attack, and $k_{1}$ is the
Table 1 Rate constants and activation parameters for the substitution reactions of complexes 1 and 2 with L-His $(25 \mathrm{mM}$ Hepes buffer, $30 \mathrm{mM}$ $\mathrm{NaCl}, \mathrm{pH} 7.4$ )

\begin{tabular}{llllll}
\hline & $T$ & $k_{2}$ & $k_{1}$ & $\Delta H_{2}^{\ddagger}$ & $\Delta S_{2}^{\ddagger}$ \\
& {$[\mathrm{K}]$} & {$\left[10^{-2} \mathrm{M}^{-1} \mathrm{~s}^{-1}\right]$} & {$\left[10^{-4} \mathrm{M}^{-1} \mathrm{~s}^{-1}\right]$} & {$\left[\mathrm{kJ} \mathrm{mol}^{-1}\right]$} & {$\left[\mathrm{J} \mathrm{K}^{-1} \mathrm{~mol}^{-1}\right]$} \\
\hline L-His & & & & & \\
$\mathbf{1}(\mathrm{en})$ & 288 & $2.0 \pm 0.3$ & $4.0 \pm 0.3$ & $44 \pm 4$ & $-145 \pm 12$ \\
& 298 & $4.0 \pm 0.6$ & $20.0 \pm 7.0$ & & \\
& 310 & $7.0 \pm 0.4$ & $34.0 \pm 4.0$ & & \\
2 (dach) & 310 & $3.6 \pm 0.3$ & $33 \pm 2.0$ & & \\
& & & & &
\end{tabular}

rate constant for the reverse reaction. The second-order rate constants $k_{2}$ are obtained directly from the slopes of the plots of $k_{\text {obsd }}$ versus the concentration of the entering nucleophile, whereas the $k_{1}$ values are derived from the intercepts divided by $\left[\mathrm{Cl}^{-}\right]$(i.e., $30 \mathrm{mM}$ ). Their values are listed in Table 1 . The rate of the reaction is described by eqn (2) and (3):

$$
\begin{gathered}
-\frac{\mathrm{d}[\mathrm{Ru}(\mathrm{Cl}-\mathrm{tpy})(\mathrm{N}-\mathrm{N}) \mathrm{Cl}]^{+}}{\mathrm{d} t}=k_{\mathrm{obsd}}[\mathrm{Ru}(\mathrm{Cl}-\mathrm{tpy})(\mathrm{N}-\mathrm{N}) \mathrm{Cl}]^{+} \\
k_{\mathrm{obsd}}=k_{1}\left[\mathrm{Cl}^{-}\right]+k_{2}[\mathrm{~L}]
\end{gathered}
$$

All kinetic runs could be fitted by a single exponential function and no subsequent reaction was observed. Each pseudofirst-order rate constant, $k_{\text {obsd }}$, was calculated as the average value of two or three independent runs and are given in Tables $\mathrm{S} 1$ and $\mathrm{S} 2 . \dagger$

The experimental results for the substitution reactions of the two complexes with L-His are shown in Fig. 3 and S6, $\dagger$ respectively. A linear dependence on the nucleophile concentration was observed for all reactions. The activation parameters $\left(\Delta H^{\star}\right.$ and $\Delta S^{\ddagger}$ ), obtained from Eyring plots (Fig. $\mathrm{S} 7 \dagger$ ), are summarized in Table 1 . It could be seen that the $\Delta S^{\ddagger}$ value is negative, suggesting that the activation process was strongly dominated by bond-making. The small values of $\Delta H^{\star}$ and the negative value of $\Delta S^{\star}$ clearly support the associative mechan-

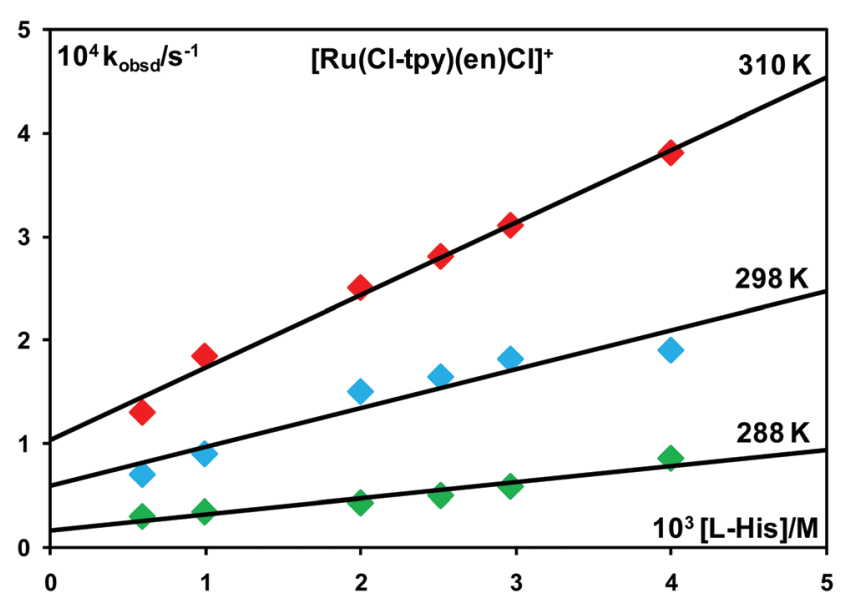

Fig. 3 Pseudo-first-order rate constants, $k_{\text {obsd, }}$ plotted as a function of ligand concentration and temperature for the substitution reactions of complex (1) with L-His in $25 \mathrm{mM}$ Hepes buffer ( $30 \mathrm{mM} \mathrm{NaCl}, \mathrm{pH}$ 7.4). 
ism for the substitution process. Similar mechanisms have been proposed for the substitution reactions of organometallic $\mathrm{Ru}(\mathrm{II})$-arene complexes, half sandwich $\mathrm{Ru}(\mathrm{II})-[9] \mathrm{aneS3}$ coordination compounds and selected $\mathrm{Ru}(\mathrm{II})$-tpy complexes investigated in previous studies with biologically relevant nucleophiles, e.g., 9-methylguanine (9MeG), guanosine (Guo), guanosine-5'-monophosphate (5'-GMP), L-His, thiourea (Tu), L-cysteine (L-Cys), L-methionine (L-Met), pyrazole (Pz), 1,2,4-triazole (Tz) and pyridine (Py). ${ }^{30,43-45}$

Histidine has three possible binding sites for metal ions: the carboxylate $(\mathrm{COO})$, the amine $\left(\mathrm{NH}_{2}\right)$ and the imidazole $\left(\mathrm{H}_{3} \mathrm{~N}_{2} \mathrm{C}_{3}\right)$ groups. The $\mathrm{p} K_{\mathrm{a}}$ values of these groups are 1.70, 9.09 and $6.04,{ }^{46,47}$ respectively. Since the nitrogen atom of the imidazole ring is a strong donor, the imidazole group is the most probable site for coordination to ruthenium(II). Moreover, as the $\mathrm{p} K_{\mathrm{a}}$ value of this group is 6.04 , it was fully deprotonated in the reaction medium $(\mathrm{pH}=7.4)$. The coordination of $\mathrm{Ru}(\mathrm{II})-\mathrm{tpy}$ complexes via the imidazole ring was supported by ${ }^{1} \mathrm{H}$ NMR spectroscopy.

It can be seen that the rate constants depend on the nature of the inert chelating ligand: complex 1 reacts $c a .2$ times faster than complex 2. The reactions with complex 2 were expected to be slower than those with 1 due to steric effects and the positive inductive effect of the cyclohexane ring that makes the $\mathrm{Ru}(\mathrm{II})$ centre less electrophilic and hence less reactive. ${ }^{48}$ The obtained $k_{2}$ values for the reaction of 1 (en) and 2 (dach) with L-His are $c a$. one order of magnitude lower than those for the reaction with 5'-GMP $\left(0.13-1.26 \mathrm{M}^{-1} \mathrm{~s}^{-1}\right)^{30}$ under the same conditions, implying that the guanine derivatives are better entering nucleophiles than the studied amino acid L-His. The relatively low reactivity of the ruthenium complexes 1 and 2 towards amino acid L-His before the complexes reach DNA could perhaps help the transport and delivery of active species to cancer cells and allow some proteins to serve as drug reservoirs for DNA ruthenation. ${ }^{20,22}$

In a previous study, the interactions of $\mathrm{Ru}(\mathrm{II})$-tpy complexes with $\mathrm{N}$-containing $(\mathrm{Pz}, \mathrm{Tz}$ and $\mathrm{Py})$ heterocycles were also studied. ${ }^{45}$ The reactivity of nitrogen-donor ligands followed the order: $\mathrm{L}$-His $>\mathrm{Pz}>\mathrm{Tz}>\mathrm{Py}$. The enhanced reactivity of $\mathrm{L}$-His compared to $\mathrm{Pz}, \mathrm{Tz}$ and $\mathrm{Py}$ is in accordance with the basicity of the coordinating nitrogen donor: the more basic $\mathrm{L}-\mathrm{His}\left(\mathrm{p} K_{\mathrm{a}}=\right.$ 6.04) reacts 1.5-3.0 times faster than the less basic $\mathrm{Pz}\left(\mathrm{p} K_{\mathrm{a}}=\right.$ 2.52) and $\mathrm{Tz}\left(\mathrm{p} K_{\mathrm{a}}=2.19\right) .{ }^{47,49,50}$ On the other hand, the lowest reactivity of Py could be explained by the steric effect and delocalization of the electrons from the nitrogen atom. ${ }^{49}$

NMR studies supported by DFT calculations. The reactions of complexes 1 and 2 with the amino acid L-His were also investigated by ${ }^{1} \mathrm{H}$ NMR in $\mathrm{D}_{2} \mathrm{O}$ at $295 \mathrm{~K}$ for a period of several days (for the numbering scheme see Fig. 1). The assignments of selected resonances of the products are reported in Table S3. $\dagger$

Addition of L-His to an equilibrated solution of 1 (1:1, $10 \mathrm{mM}, \mathrm{pH}=5.35)$ in $\mathrm{D}_{2} \mathrm{O}$ induced slow changes in the ${ }^{1} \mathrm{H}$ NMR spectrum (Fig. S8†). In comparison with those of the free $\mathrm{L}-\mathrm{His}$, the $\mathrm{H} 2_{\mathrm{L}-\mathrm{His}}$ peak of the L-His ligands of adduct $5 \mathbf{a}$ shifted to a high field by $1.26 \mathrm{ppm}$, whereas the peak for the $\mathrm{H} 2_{\mathrm{L}-\mathrm{His}}$ proton of adduct $\mathbf{5 b}$ shifted to a high field by $1.15 \mathrm{ppm}$ (Table $\mathrm{S} 3 \dagger$ ). The $\mathrm{H}_{5} 5_{\mathrm{L}-\mathrm{His}}$ peak of adduct $\mathbf{5 b}$ was also remarkably shifted to a high field by $1.02 \mathrm{ppm}$. It is assumed that $\mathrm{Ru}(\mathrm{II})$ in adduct $5 \mathbf{a}$ binds to the $\mathrm{N} 3$ atom, and to $\mathrm{N} 1$ in adduct $\mathbf{5 b}$ (Scheme 2). The system reached equilibrium after ca. 2 days with $c a .10 \%$ of unbound L-His. Sadler et al. also reported the formation of both L-His adducts with an organometallic ruthenium arene complex, which were identified by electrospray ionization mass spectrometry and NMR spectroscopy. ${ }^{41}$ In order to confirm that adduct 5a was an N3-bound histidine complex $[\mathrm{Ru}(\mathrm{Cl}-\mathrm{tpy})(\mathrm{en})(\mathrm{L}-\mathrm{His}-\mathrm{N} 3)]^{2+}$, and adduct $\mathbf{5 b}$ an N1bound histidine product $[\mathrm{Ru}(\mathrm{Cl}-\mathrm{tpy})(\mathrm{en})(\mathrm{L}-\mathrm{His}-\mathrm{N} 1)]^{2+}$, quantum chemical model calculations were performed.

Similar results were obtained with $\left[\mathrm{Ru}(\mathrm{Cl} \text {-tpy })(\text { dach })\left(\mathrm{H}_{2} \mathrm{O}\right)\right]^{2+}$ (2a, $10 \mathrm{mM}, \mathrm{pH}=5.13$ ) (Fig. 4) with the formation of an N3 complex $\left[\mathrm{Ru}(\mathrm{Cl}-\mathrm{tpy})(\text { dach)(L-His-N3) }]^{2+}(\mathbf{6 a})\right.$ and an N1 product $[\mathrm{Ru}(\mathrm{Cl}-\mathrm{tpy})(\mathrm{dach})(\mathrm{L}-\mathrm{His}-\mathrm{N} 1)]^{2+}(\mathbf{6 b})$. The system reached equilibrium after $c a$. 2 days with $c a .11 \%$ of unbound L-His.

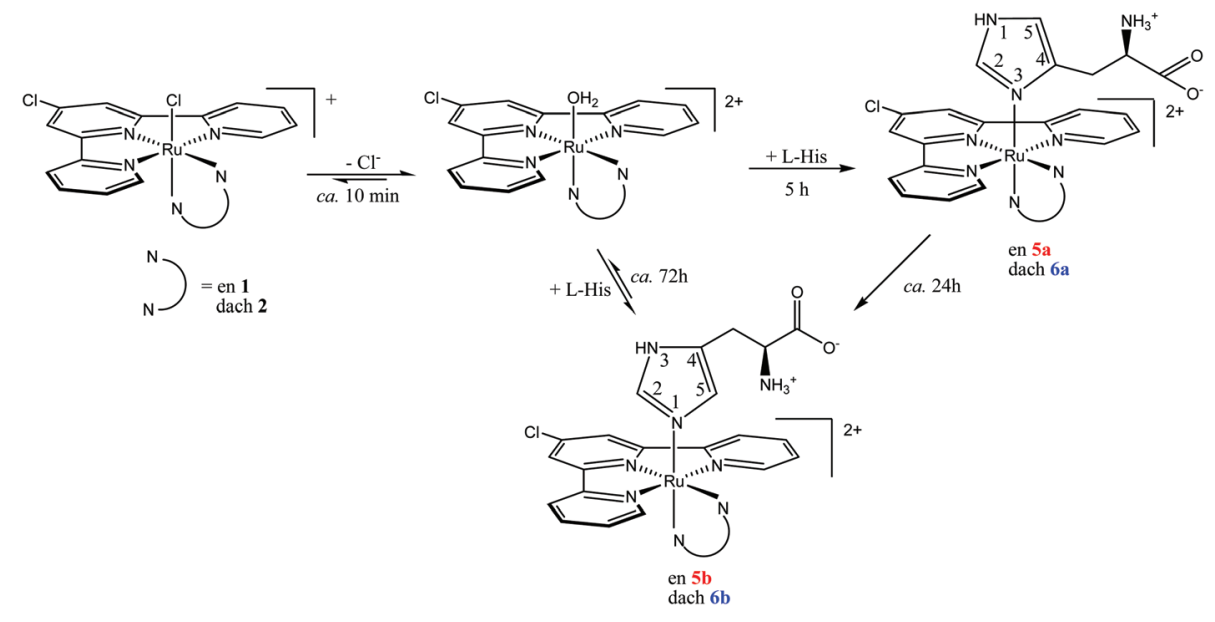

Scheme 2 Reaction pathways of $[\mathrm{Ru}(\mathrm{Cl}-\mathrm{tpy})(\mathrm{N}-\mathrm{N}) \mathrm{Cl}]^{+}$complexes with L-His in aqueous solutions. 

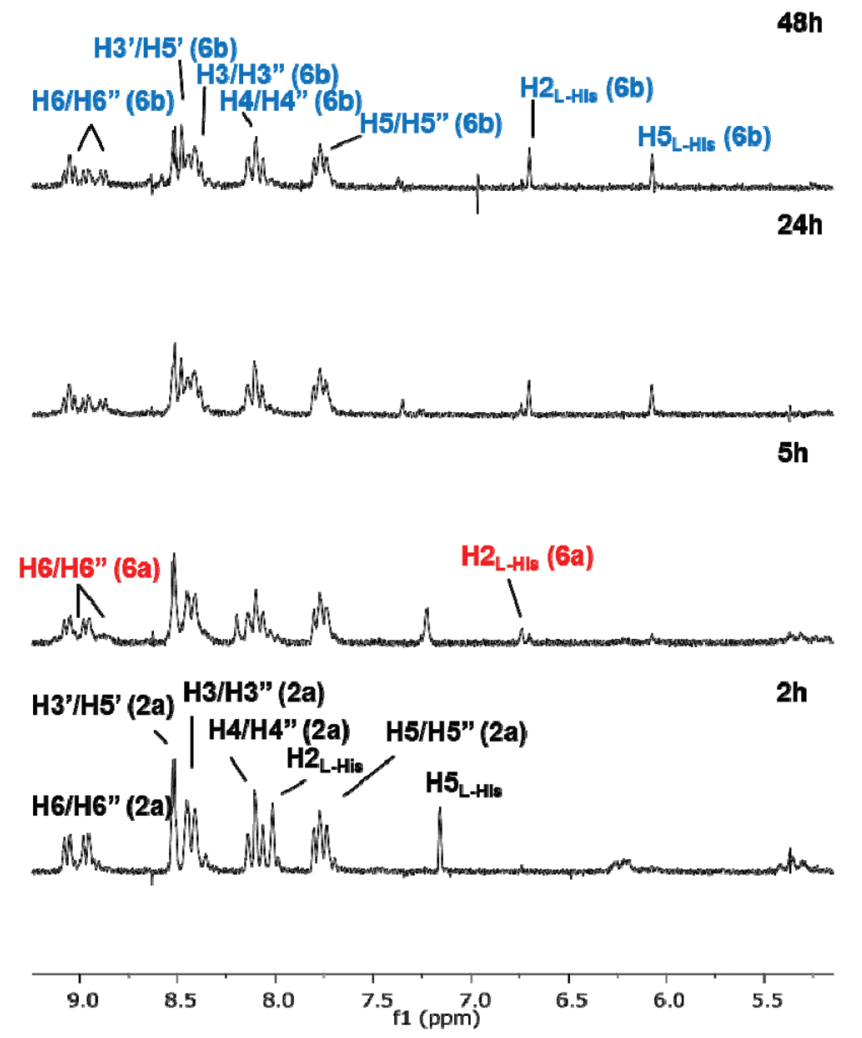

Fig. $4{ }^{1} \mathrm{H}$ NMR spectra of $\left[\mathrm{Ru}(\mathrm{Cl} \text {-tpy })(\text { dach })\left(\mathrm{H}_{2} \mathrm{O}\right)\right]^{2+}(2 \mathrm{a}, 10 \mathrm{mM})$ at various time intervals after the addition of $\mathrm{L}-\mathrm{His}(1$ eq., $\mathrm{pH}=5.13,295 \mathrm{~K})$.

To corroborate these findings by an independent and different method, quantum chemical calculations on the $\left[\mathrm{Ru}(\mathrm{Cl} \text {-tpy)(en)Cl}]^{+}\right.$and $\left[\mathrm{Ru}(\mathrm{Cl} \text {-tpy)(dach)Cl }]^{+}\right.$systems were performed. Calculations with an amino acid such as L-His led to two problems that have to be consider: (i) while amino acids are zwitterionic in solution, in the gas phase they tend to prevent charge separation ${ }^{51}$ and (ii) the COO-moiety of L-His can form an artificial hydrogen bond with the $\mathrm{H}_{2} \mathrm{~N}$-group of en and dach, prevented in solution by the surrounding water molecules. To overcome these problems, we calculated at first the $[\mathrm{Ru}(\mathrm{Cl}-\mathrm{tpy})(\mathrm{en}) \mathrm{Cl}]^{+}$and $\left[\mathrm{Ru}(\mathrm{Cl} \text {-tpy)(dach)Cl }]^{+}\right.$complexes with the model compound 4-methylimidazole instead of L-His, as this hetero aromatic system has no possibility of forming hydrogen bonds with the $\mathrm{H}_{2} \mathrm{~N}$-groups. Independently, whether solvent effects were included via CPCM or not, always the isomer coordinating 4-methylimidazole by N1 was clearly favored by around $5 \mathrm{kcal} \mathrm{mol}^{-1}$ (see Fig. S9†). This preferred coordination was also visible in the somewhat shorter $\mathrm{Ru}-\mathrm{N}$ bond in the N1-coordinated isomer compared to the N3-coordinated one (2.14-2.17 $\AA$ ). Comparison of the other $\mathrm{Ru}-\mathrm{N}$-interactions shows no remarkable differences in all four structures (see Fig. S9†).

After corroborating the preferred unhampered coordination of 4-methylimidazole to the $\mathrm{Ru}(\mathrm{II})$-center via the N1-atom, we tested the complete complex system applying B3LYP(CPCM)/ LANL2DZp. The inclusion of the solvent model is an often applied technique to prevent the back migration of protons in the zwitterionic form that leads to neutral uncharged amino acids. While the applied solvent model allowed the calculations of the zwitterionic species, still the influence of the hydrogen bond between the COO-moiety and the $\mathrm{H}_{2} \mathrm{~N}$-groups of en and dach had to be considered. To specify the contribution of this hydrogen bond, the complexes where L-His is coordinated via the N1-nitrogen and the isomer with N3-coordination were calculated. In the case of the N3-bound form, two rotamers, both of which are a local minimum on the energy hypersurface, one with and one without the $\mathrm{COO}-\mathrm{H}_{2} \mathrm{~N}$-hydrogen bond, were calculated (see Fig. 5 and $\mathrm{S} 10 \dagger)$.

Comparison of the N1- and the N3-coordinated complexes without additional hydrogen bonds shows clearly that the N3 bound L-His is clearly less stable by nearly $4 \mathrm{kcal} \mathrm{mol}^{-1}$, independent of whether $\left[\mathrm{Ru}(\mathrm{Cl} \text {-tpy)(en)(L-His) }]^{2+}\right.$ or $[\mathrm{Ru}(\mathrm{Cl}$-tpy) (dach)(L-His) $]^{2+}$ was investigated (see Fig. 5 and S10 ${ }^{\dagger}$ ). Considering the artificial but possible inner molecular hydrogen bond between the $\mathrm{H}_{2} \mathrm{~N}$-moiety and the COO-group of $\mathrm{L}$-His results in an inconsistent picture, strongly dependent on the strength of the hydrogen bond. While in $[\mathrm{Ru}(\mathrm{Cl}-t$ tpy)(en) $(\mathrm{L}-\mathrm{His})]^{2+}$, the inner molecular hydrogen bond is $1.83 \AA$ long and stabilizes the N3-coordination of $\mathrm{L}_{\text {-His }}$ by $2.8 \mathrm{kcal} \mathrm{mol}^{-1}$ (compared to the complex without the inner molecular hydrogen bond), [Ru(Cl-tpy)(dach)(L-His) $]^{2+}$ has a $0.1 \AA$ A shorter inner molecular hydrogen bond and the system is stabilized by nearly $5 \mathrm{kcal} \mathrm{mol}^{-1}$. Due to this $\mathrm{H}$-bond, the N3 coordination seems to be at a first glance $1 \mathrm{kcal} \mathrm{mol}^{-1}$ more stable in $[\mathrm{Ru}(\mathrm{Cl}-\mathrm{tpy})(\mathrm{dach})(\mathrm{L}-\mathrm{His})]^{2+}$ than the N1 bound case. While this special effect was taken care of in the calculations, in the experimentally applied aquatic solution, the water molecules will prevent the described inner molecular hydrogen bonding by complexes-water-hydrogen bonds. Such an explicit water molecule-complex interaction cannot be modeled with the applied CPCM-solvent model and would require molecular dynamic simulations, which are beyond the scope of this study.

A comparison of the calculated structures shows significantly shorter N1-Ru bonds $(2.13 \AA)$ than N3-Ru interactions. Of course, shorter N3-Ru bonds (2.18 $\mathrm{A})$ were found in complexes without extra inner molecular stabilization, while the hydrogen bonded rotamers with extra stabilization were the longest (2.22/2.21 $\AA$ ). All other Ru-N-complex bonds showed no significant differences in the investigated systems (see Fig. 5 and $\mathrm{S} 10 \dagger$ ).

The NMR time course supported by DFT calculations allowed the reaction pathways as shown in Scheme 2 to be drawn. L-His binds to Ru(II)-tpy complexes either through the N3 or N1 nitrogen atom of the imidazole ring. During the time course of the reaction, the complete migration of the $\mathrm{Ru}$ fragment from N3 to N1 occurs. Both N3 and N1 coordinated histidine complexes of $\mathrm{Ru}(\mathrm{II})$ have been reported previously. ${ }^{41,42,52-54}$ It has also been reported that the amino group $^{52,53}$ and the carboxylate group of histidine can bind to $\mathrm{Ru}(\mathrm{II})$ to form five-membered and/or six-membered chelate rings when coordination sites were available. In the present case, only one coordination site was available on $\mathrm{Ru}(\mathrm{II})$ and 


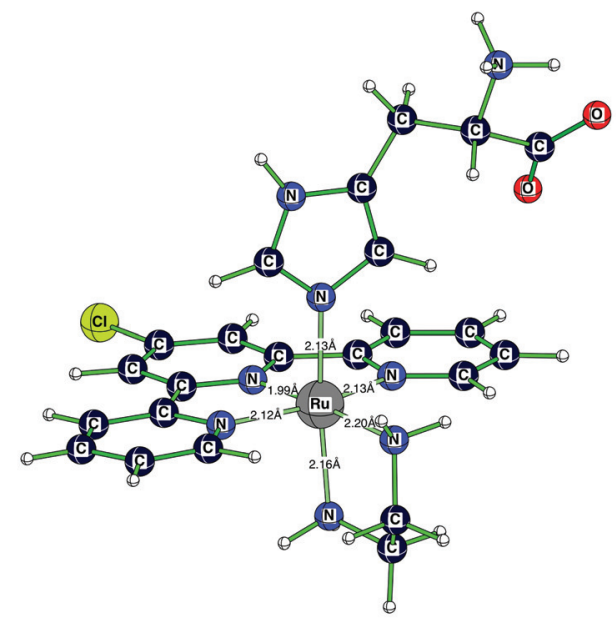

$0.0 \mathrm{kcal} \mathrm{mol}^{-1}$

N1-coordinated L-His in $\left[\mathrm{Ru}(\mathrm{Cl} \text {-tpy)(en)(L-His) }]^{2+}\right.$

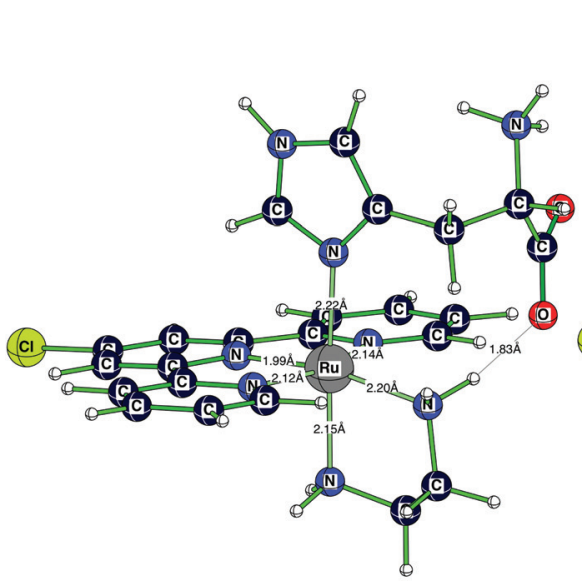

$0.9 \mathrm{kcal} \mathrm{mol}^{-1}$

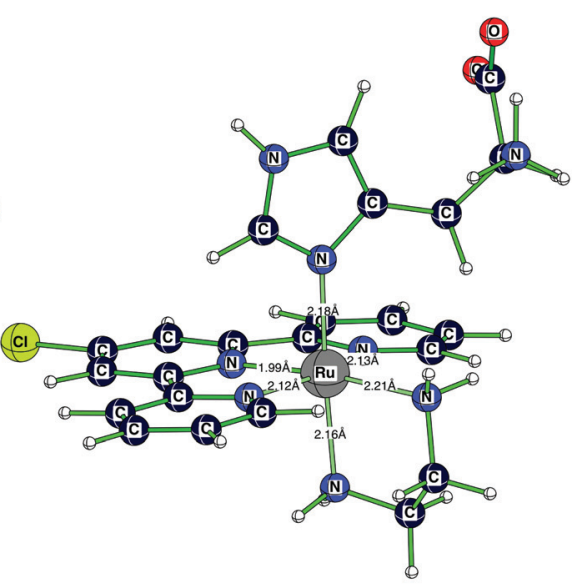

$3.7 \mathrm{kcal} \mathrm{mol}^{-1}$

$\mathrm{N} 3$-coordinated L-His in $[\mathrm{Ru}(\mathrm{Cl}-\mathrm{tpy})(\mathrm{en})(\mathrm{L}-\mathrm{His})]^{2+}$ with and without an inner molecular hydrogen bond

Fig. 5 Calculated (B3LYP(CPCM)/LANL2DZp) N1- and N3-bound isomeric structures and energies (B3LYP(CPCM)/LANL2DZp + ZPE(B3LYP(CPCM)/ LANL2DZp)) of $\left[\mathrm{Ru}(\mathrm{Cl} \text {-tpy)(en)(L-His) }]^{2+}\right.$. In the case of the N3-coordinated species, rotamers with and without an inner molecular hydrogen bond were considered.

N3 and N1 coordinations were favored over amino and carboxylate binding.

Lipophilicity. Octanol-water partition coefficients $\left(\log P_{\mathrm{o} / \mathrm{w}}\right)$ provide a measure of drug lipophilicity, which indicates the ability of a molecule to pass through cell membranes. ${ }^{55}$ The lipophilicity of complexes $\mathbf{1}$ and $\mathbf{2}$ was determined by measuring the concentration ratio of the corresponding complex in the aqueous phase in the equilibrium state. After mixing with octanol and water, complexes $\mathbf{1}$ and $\mathbf{2}$ were distributed mostly in the aqueous phase. Both complexes gave negative $\log P_{\mathrm{o} / \mathrm{w}}$ values, showing them to be hydrophilic in nature. Complex 1 tended to be less hydrophilic $(-1.33)$ compared to complex 2 $(-1.45)$, which may facilitate its cell uptake efficiency and enhance its anticancer activity.

\section{DNA-binding studies}

Absorption spectroscopic studies. As DNA is an important potential biological target for many metal-based anticancer agents, ${ }^{56,57}$ distortions of the DNA structure often correlate with anticancer activity. ${ }^{58,59}$ Therefore, it is of great importance to understand DNA binding properties of potential anticancer agents. The general aim was to investigate the effects of the planarity of the tpy ligand and the nature of the chelating ligands on the binding mode of Ru(II)-tpy complexes to DNA and to relate this to the differences in their anticancer activity. As is known, transition metal complexes can bind to DNA via both covalent (replacement of a labile ligand of the complex by a nitrogen base of DNA, e.g., guanine N7) and/or 
non-covalent (intercalation, electrostatic or groove binding) interactions. ${ }^{60,61}$

The application of electronic absorption spectroscopy is one of the most universally employed methods for the determination of the binding modes and the binding extent of metal complexes with DNA. The absorption intensity of complexes may decrease (hypochromism) or increase (hyperchromism) with a slight increase in the absorption wavelength (bathochromism) upon the addition of DNA. The absorption spectra of complexes 1 and 2 in the absence and presence of CT DNA (at a constant concentration of the complexes) are given in Fig. S11. $\dagger$ The increase in the intensity at the MLCT band for both complexes indicated that the interaction with CT DNA resulted in the direct formation of a new complex with doublehelical CT DNA. In the UV spectrum of complex 1 (Fig. S11†), the band centered at $493 \mathrm{~nm}$ presents a hyperchromism, suggesting the tight binding and stabilization of the CT DNA duplex. Additionally, the bands at 222 and $291 \mathrm{~nm}$ present a hyperchromism and a red shift (bathochromism) of $5 \mathrm{~nm}$ (up to 227 and $297 \mathrm{~nm}$ ), suggesting the presence of combined covalent (N7 coordination) and non-covalent intercalative binding of the complex to DNA by the insertion of the planar aromatic ligand tpy between adjacent base pairs on the DNA duplex. The behavior of complex 2 was quite similar (the band centered at $495 \mathrm{~nm}$ presents a hyperchromism) upon the addition of increasing amounts of CT DNA (Fig. S11†). Both bands centered at 223 and $291 \mathrm{~nm}$ present a hyperchromism, while the first band is red-shifted towards $229 \mathrm{~nm}$ and the second towards $299 \mathrm{~nm}$. It is important to emphasize that the studied complexes contain both a leaving group and a DNA intercalating ligand, and hence, they could interact with DNA in a bifunctional mode, including covalent binding to the nucleobases and non-covalent intercalation. Moreover both complexes contain $\mathrm{N}$-donor chelating ligands that are able to form specific hydrogen bonds. These observations are in accordance with those obtained for anticancer $\mathrm{Ru}(\mathrm{II})$-arene complexes. $^{60,62}$

The intrinsic binding constants $K_{\mathrm{b}}$ of complexes 1 and 2 were $(1.0 \pm 0.2) \times 10^{5} \mathrm{M}^{-1}$ and $(2.1 \pm 0.1) \times 10^{4} \mathrm{M}^{-1}$, respectively (see Table 2). The $K_{\mathrm{b}}$ values suggest strong binding of the complexes to CT DNA, with complex 1 exhibited higher $K_{\mathrm{b}}$ values compared to complex 2. However, they are lower than those of the classical intercalator EB, the binding affinity for CT DNA of which is given by $K_{\mathrm{b}}=1.23( \pm 0.07) \times 10^{5} \mathrm{M}^{-1} \cdot{ }^{63-65}$

Fluorescence quenching studies. Ethidium bromide (EB) is a classical intercalator that gives significant fluorescence emission intensity when it intercalates into the basis pairs of DNA.

Table 2 The DNA-binding constants $\left(K_{\mathrm{b}}\right)$ and Stern-Volmer constants $\left(K_{\mathrm{sv}}\right)$ from EB-DNA fluorescence for complexes 1 and 2

\begin{tabular}{lll}
\hline & $K_{\mathrm{b}}\left[\mathrm{M}^{-1}\right]$ & $K_{\mathrm{sv}}\left[\mathrm{M}^{-1}\right]$ \\
\hline$[\mathrm{Ru}(\mathrm{Cl}-\mathrm{tpy})(\mathrm{en}) \mathrm{Cl}][\mathrm{Cl}] \mathrm{1}$ & $(1.0 \pm 0.2) \times 10^{5}$ & $(2.1 \pm 0.1) \times 10^{4}$ \\
{$[\mathrm{Ru}(\mathrm{Cl}-\mathrm{tpy})(\mathrm{dach}) \mathrm{Cl}][\mathrm{Cl}] 2$} & $(2.1 \pm 0.1) \times 10^{4}$ & $(1.5 \pm 0.1) \times 10^{4}$
\end{tabular}
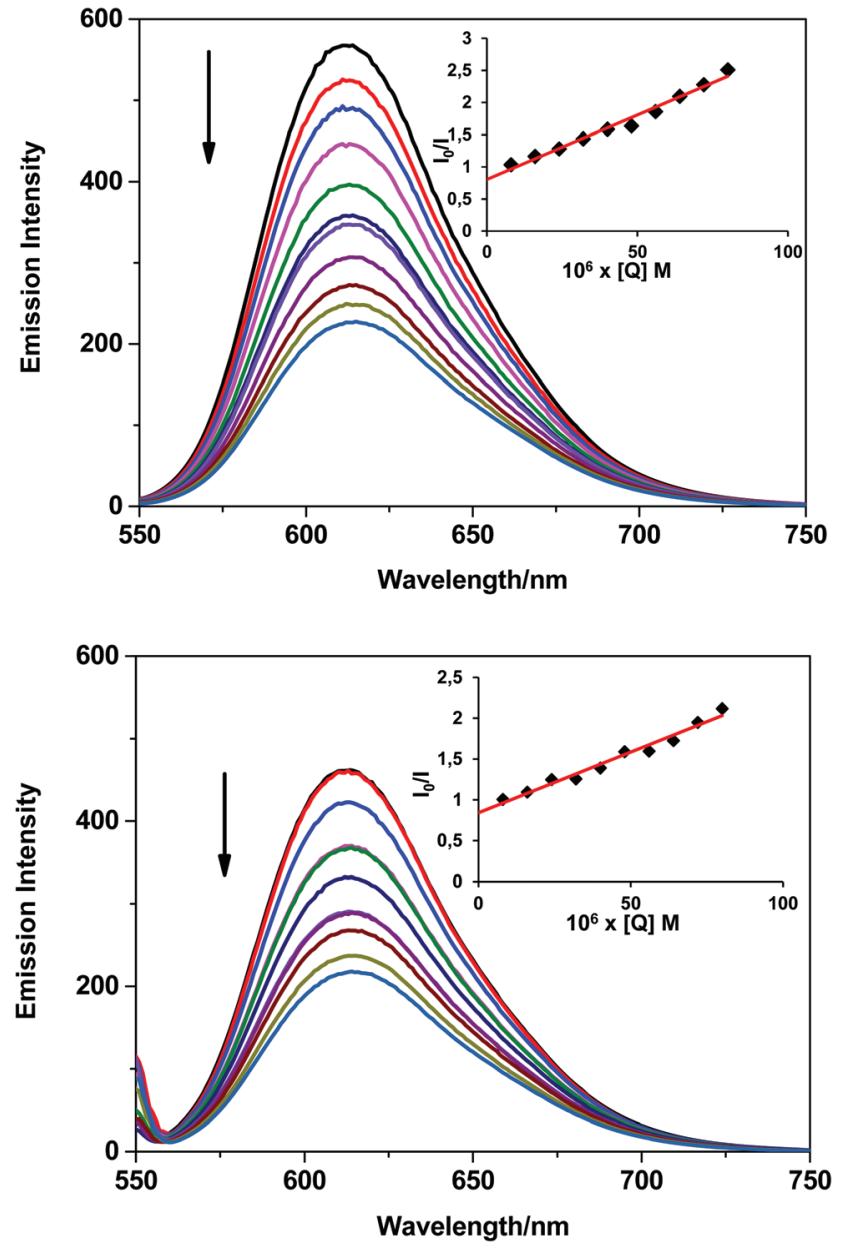

Fig. 6 Emission spectra of EB bound to DNA in the presence of complexes 1 (top) and 2 (bottom). [EB] $=80 \mu \mathrm{M}$, [DNA] $=80 \mu \mathrm{M}$; [Ru] $=$ $0-80 \mu \mathrm{M} ; \lambda_{\mathrm{ex}}=527 \mathrm{~nm}$. The arrows show the intensity changes upon increasing the concentrations of the complexes. Insets: plots of $I_{0} / I$ versus [Q], with $\bullet$ for the experimental data points and the full line for the linear fitting of the data.

When it is replaced or excluded from the internal hydrophobic circumstance of the DNA double helix by other small molecules, its fluorescence emission is effectively quenched by external polar solvent molecules such as $\mathrm{H}_{2} \mathrm{O} .{ }^{66}$ The fluorescence quenching curves of EB bound to DNA in the absence and presence of the complexes are shown in Fig. 6. The addition of complexes 1 and 2 resulted in significant decreases in the intensity of the emission band at $612 \mathrm{~nm}$, indicating competition of the compounds with EB in binding to DNA (Fig. 6). The observed quenching of DNA-EB fluorescence suggested that they displace EB from the DNA-EB complex and interact with DNA by intercalation. The planar terpyridine ligand of complexes $\mathbf{1}$ and $\mathbf{2}$ seems to have facilitated intercalation resulting in the partial replacement of EB from the DNAEB complex, resulting in the observed quenching of fluorescence. The fluorescence quenching results are in good agreement with the results obtained by UV spectroscopic studies. 
The Stern-Volmer quenching plots (Fig. 6, inset) show that the quenching of EB bound to DNA by complexes 1 and 2 is in good agreement $(R=0.97-0.98)$ with the linear Stern-Volmer equation and the values of the Stern-Volmer quenching constant $K_{\text {sv }}$ are given in Table 2. Complexes 1 and 2 showed high values of the quenching constant of $2.1 \times 10^{4}$ and $1.5 \times 10^{4}$ $\mathrm{M}^{-1}$, respectively, indicating their great efficiency to replace EB and bind strongly with DNA, which was also evident from the high values of their DNA binding constant $\left(K_{\mathrm{b}}\right)$. These additional interactions could contribute to the unique binding modes to duplex DNA and induce different structural distortions in DNA compared to cisplatin.

Overall, these combined results might suggest the presence of both covalent (coordinative) and non-covalent intercalative binding modes of DNA binding for complexes $\mathbf{1}$ and $\mathbf{2}$ upon hydrolysis. Similar observations were reported by Sadler and coworkers for organometallic complexes. For example, the direct coordinative binding of the monofunctional $\left[\mathrm{Ru}\left(\eta^{6}\right.\right.$ biphenyl)(en)Cl $]^{+}$complex to N7 of guanine bases in DNA was complemented by intercalative binding of the biphenyl ligand and specific hydrogen bonding interactions of the ethylenediamine $\mathrm{NH}_{2}$ groups with $\mathrm{C6O}$ of guanine. ${ }^{60}$

\section{Viscosity measurements}

In order to further confirm the modes of binding of complexes $\mathbf{1}$ and $\mathbf{2}$ to CT DNA, viscosity measurements of DNA solutions were performed in the presence and absence of these complexes. The viscosity of DNA is sensitive to length changes and is regarded as the least ambiguous and the most critical evidence in identifying the DNA binding mode in solution. ${ }^{67,68}$ The addition of increasing amounts (up to $r=1.0$ ) of complexes 1 and 2 to a DNA solution $(0.01 \mathrm{mM})$ resulted in an increase in the relative viscosity of DNA (Fig. S13†), which was more pronounced upon the addition of complex 1 . In the case of classic intercalation, DNA base pairs are separated to host the bound compound resulting in increased DNA viscosity, the magnitude of which is usually in accordance with the strength of the interaction, because of the lengthening of the DNA helix. Therefore, the observed viscosity increase may be explained by an increase in the overall DNA length provoked by the insertion of the compounds in between the DNA base pairs due to interaction via intercalation through the aromatic chromophore of the tpy ligand in the complexes.

\section{In vitro anticancer activity}

The cytotoxicity of five $\mathrm{Ru}(\mathrm{II})$ terpyridine complexes 1-4 and P2 was evaluated in human lung carcinoma (A549), human colon carcinoma (HCT116) and mouse colon carcinoma (CT26) cell lines by the MTT assay. For comparison purposes, the cytotoxicity of cisplatin has also been examined. The cytotoxicities of complexes 1-4 and P2 were found to be dose dependent, that is, the cell viability decreased with increasing concentration. The $\mathrm{IC}_{50}$ values of the complexes are listed in Table 3 . Complex 1, with $\mathrm{IC}_{50}$ values ranging between 32.80 and $66.30 \mu \mathrm{M}$, manifested the highest anticancer activity compared to the other four complexes (2-4 and P2), but their cytotoxicity
Table $3 \quad I C_{50}$ values for complexes 1-4 and P2 towards different cell lines in comparison with cisplatin, obtained from the MTT assay, after $72 \mathrm{~h}$ drug exposure. In all cases, the values represent the mean of three independent experiments

\begin{tabular}{lccc}
\hline & $\mathrm{IC}_{50}[\mu \mathrm{M}]$ & & \\
\cline { 2 - 4 } & $\mathrm{A} 549$ & $\mathrm{HCT} 116$ & $\mathrm{CT} 26$ \\
\hline $\mathbf{1}$ & $58.40 \pm 0.10$ & $66.30 \pm 0.20$ & $32.80 \pm 0.10$ \\
$\mathbf{2}$ & $110.80 \pm 0.30$ & $84.40 \pm 0.10$ & $72.80 \pm 0.20$ \\
$\mathbf{4}$ & $>250$ & $>250$ & $>250$ \\
P2 & $>1000$ & $>1000$ & $>1000$ \\
Cisplatin & $>250$ & $>250$ & $>250$ \\
& $33.00 \pm 0.10$ & $45.10 \pm 0.20$ & $24.70 \pm 0.10$ \\
\hline
\end{tabular}

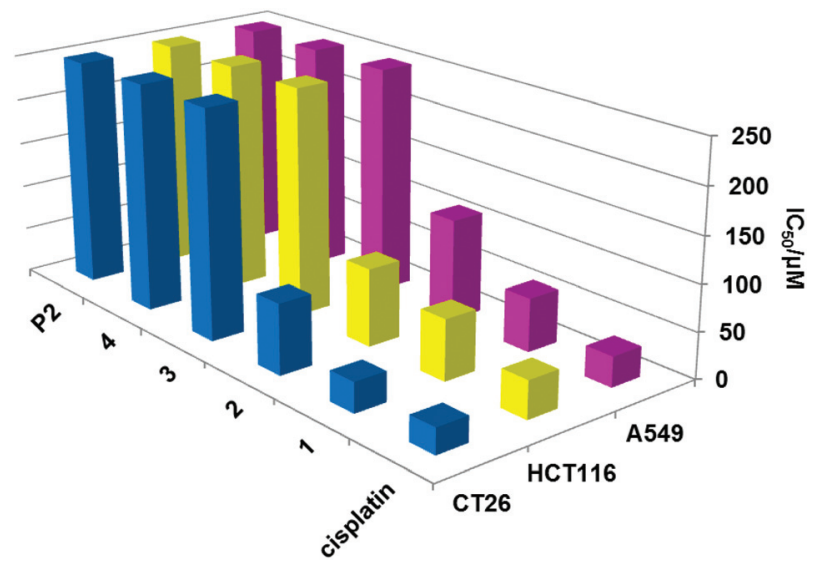

Fig. $7 \quad \mathrm{IC}_{50}$ values for cisplatin and complexes 1-4 and P2 after incubation with different cancer cell lines for $72 \mathrm{~h}$.

was lower than cisplatin under the same conditions (Fig. 7). The $\mathrm{IC}_{50}$ values of the tested complexes roughly correlated with their ability to hydrolyze the monodentate ligand at a reasonable rate. In fact, both $\mathrm{Ru}(\mathrm{II})$-tpy complexes $\mathbf{1}$ and $\mathbf{2}$ rapidly equilibrated with the corresponding aqua species upon dissolution in water, while complexes $\mathbf{3}$ and $\mathbf{4}$ were very inert in aqueous solution. In addition, the cytotoxicity was found to be dependent on the nature of the inert chelating ligand. The presence of ethylenediamine in the coordination sphere of the ruthenium(II) terpyridine complexes is very important for the cytotoxic activity. These results seemed to be in agreement with the lipophilic character $\left(\log P_{\mathrm{o} / \mathrm{w}}\right)$ of complexes $\mathbf{1}$ and 2 .

A loss of cytotoxicity towards cancer cells was observed for selected complexes when en and dach, $\sigma$-donors, are replaced by other $\mathrm{N}-\mathrm{N}$ chelates (bpy) or by $\mathrm{N}-\mathrm{O}$ anionic ligand (pic), a strong $\pi$-acceptor. From a structural point of view, loss of activity in these derivatives could arise from the absence of $\mathrm{N}_{\left(\mathrm{sp}^{3}\right)} \mathrm{H}$ groups, which are known to stabilize nucleobase adducts through strong hydrogen bonds between an $\mathrm{NH}$ of en and $\mathrm{C6O}$ from the guanine nucleobase. ${ }^{45,60}$ Similar observations have been reported for the activity of the half-sandwich $\mathrm{Ru}(\mathrm{II})-[9] \mathrm{aneS} 3$ complexes and for the half-sandwich organometallic compounds. ${ }^{17,69,70}$ 


\section{Experimental}

\section{Materials}

1,2-Diaminoethane (en), ( \pm )-trans-1,2-diaminocyclohexane (dach), 2,2'-bipyridine (bpy), 4'-chloro-2,2':6',2"-terpyridine (Cltpy), 2,2':6',2"-terpyridine (tpy), and L-histidine were commercially available and used as received. K(pic) was obtained by treatment of Hpic with excess $\mathrm{KOH}$ in ethanol. The precursors $\left[\mathrm{Ru}\left(\mathrm{Cl}\right.\right.$-tpy) $\left.\mathrm{Cl}_{3}\right]$ (P1) and $\left[\mathrm{Ru}(\mathrm{tpy}) \mathrm{Cl}_{3}\right]$ (P2) were prepared as described in the literature. ${ }^{30,71}$ The complexes $[\mathrm{Ru}(\mathrm{Cl}$-tpy)(en) $\mathrm{Cl}][\mathrm{Cl}](1),[\mathrm{Ru}(\mathrm{Cl}-\mathrm{tpy})(\mathrm{dach}) \mathrm{Cl}][\mathrm{Cl}](2)$ and $[\mathrm{Ru}(\mathrm{Cl}-\mathrm{tpy})(\mathrm{bpy}) \mathrm{Cl}]$ [Cl] (3) were synthesized as reported previously. ${ }^{30}$ Microanalysis and UV-Vis and ${ }^{1} \mathrm{H}$ NMR spectroscopy were used to check the purity of the complexes and the spectra agreed well with the data already reported. All other chemicals were used as purchased without further purification. Doubly distilled water was used as the solvent throughout the experiments. A stock solution of CT DNA was prepared in $10 \mathrm{mM}$ Tris- $\mathrm{HCl} / 150 \mathrm{mM}$ $\mathrm{NaCl}$ buffer at $\mathrm{pH}=7.4$, which gave a ratio of UV absorbances at $260 \mathrm{~nm}$ and $280 \mathrm{~nm}\left(A_{260} / A_{280}\right)$ of $c a .1 .8-1.9$, indicating that the DNA was sufficiently free of proteins and the concentration was determined by the UV absorbance at $260 \mathrm{~nm}(\varepsilon=$ $\left.6600 \mathrm{M}^{-1} \mathrm{~cm}^{-1}\right) .^{72}$

\section{Instrumental methods}

The mono- $\left({ }^{1} \mathrm{H}(500 \mathrm{MHz}),{ }^{13} \mathrm{C}(126 \mathrm{MHz})\right)$ and bi-dimensional $\left({ }^{1} \mathrm{H}-{ }^{1} \mathrm{H}\right.$ COSY, ${ }^{1} \mathrm{H}-{ }^{13} \mathrm{C}$ HSQC, ${ }^{1} \mathrm{H}_{-}-{ }^{13} \mathrm{C}$ HMBC) NMR spectra were recorded on a Varian 500 spectrometer. The ${ }^{1} \mathrm{H}$ chemical shifts in $\mathrm{D}_{2} \mathrm{O}$ were referenced to the internal standard 2,2dimethyl-2,2-silapentane-5-sulfonate (DSS) at $\delta=0.00$ or to added 1,4-dioxane $(\delta=3.75)$, whereas in $\mathrm{CD}_{3} \mathrm{CN}$, they were referenced to the peak of the residual non-deuterated solvent $(\delta=1.94) ;{ }^{13} \mathrm{C}$ chemical shifts in $\left(\mathrm{CD}_{3}\right)_{2} \mathrm{CO} / \mathrm{D}_{2} \mathrm{O}(6: 1)$ were referenced to the peak of the residual non-deuterated solvent $(\delta=29.84)$. All NMR spectra were run at $298 \mathrm{~K}$. The UV-Vis spectra were obtained on a Perkin-Elmer Lambda 35 double beam spectrophotometer using $1.0 \mathrm{~cm}$ path-length quartz cuvettes $(3.0 \mathrm{~mL})$. The infrared spectra were recorded on a Perkin-Elmer 983G spectrometer. Elemental analysis was performed at the Dipartimento di Scienze e Tecnologie Chimiche, University of Udine (Italy). Fluorescence measurements were run on a RF-1501 PC spectrofluorometer (Shimadzu, Japan). The fluorescence spectra were recorded in the range $550-750 \mathrm{~nm}$ upon excitation at $527 \mathrm{~nm}$ in all cases. The excitation and emission bandwidths were both $10 \mathrm{~nm}$. Viscosity experiments were performed using an Ubbelodhe viscometer maintained at a constant temperature of $25.0 \pm 0.1{ }^{\circ} \mathrm{C}$ in a thermostatic bath.

\section{Synthesis of the complex [Ru(Cl-tpy)(pic)Cl] (4)}

$\left[\mathrm{Ru}\left(\mathrm{Cl}\right.\right.$-tpy) $\left.\mathrm{Cl}_{3}\right]$ (P1) $(50.0 \mathrm{mg}, 0.105 \mathrm{mmol})$ was suspended in $10 \mathrm{~mL}$ of an ethanol $/ \mathrm{H}_{2} \mathrm{O}(3: 1)$ mixture containing $44.5 \mathrm{mg}$ (1.050 mmol, 10 eq.) of $\mathrm{LiCl}$ and $43.9 \mu \mathrm{l}$ (0.315 mmol, 3 eq.) of triethylamine $\left(\mathrm{Et}_{3} \mathrm{~N}\right)$ as a reductant. The chelating ligand pic (20.3 $\mathrm{mg}, 0.126 \mathrm{mmol}, 1.2 \mathrm{eq}$.) was then added and the reaction mixture was refluxed for $c a .4 \mathrm{~h}$ under vigorous stirring.
During this time, the color of the solution changed from purple to red. The solution was filtered while hot to remove any undissolved material. Rotary concentration under reduced pressure to $\mathrm{ca} . \frac{1}{4}$ of the initial volume and storage at $4.0^{\circ} \mathrm{C}$ for $24 \mathrm{~h}$ induced the formation of the product as a dark solid. It was collected by filtration, washed with ethanol and diethyl ether and vacuum dried. Yield: $40.3 \mathrm{mg}$ (73\%). Anal. Calcd for $\mathrm{C}_{21} \mathrm{H}_{14} \mathrm{Cl}_{2} \mathrm{~N}_{4} \mathrm{O}_{2} \mathrm{Ru}$ (FW: 526.34): C, 47.9; H, 2.68; N, 10.64\%. Found: C, 47.9; H, 2.71; N, 10.62\%. Complex 4 is soluble in dichloromethane, nitromethane and acetonitrile, partially soluble in water and methanol, whereas it is insoluble in ethanol, acetone and chloroform. ${ }^{1} \mathrm{H} \mathrm{NMR}\left(\left(\mathrm{CD}_{3}\right)_{2} \mathrm{CO} / \mathrm{D}_{2} \mathrm{O}\right.$ $(6: 1)$; the shifts were referenced to the internal standard DSS at $\delta=0.00): 8.68\left(\mathrm{~s}, 2 \mathrm{H}, \mathrm{C}^{\prime} H / \mathrm{C}^{\prime} H\right), 8.64(\mathrm{~d}, 2 \mathrm{H}, J=4.8 \mathrm{~Hz}$, C6H/C6"H), 8.62 (d, 2H, $J=8.0 \mathrm{~Hz}, \mathrm{C} 3 H / \mathrm{C} 3 " H), 8.04$ (t, $2 \mathrm{H}, J=$ $7.3 \mathrm{~Hz}, \mathrm{C} 4 H / \mathrm{C} 4 " H$ ), 8.02 (d, 1H, $J=7.9 \mathrm{~Hz}, \mathrm{C} 3 H$ pic), 7.70 (t, $2 \mathrm{H}, J=6.6 \mathrm{~Hz}, \mathrm{C} 5 H / \mathrm{C} 5 " H), 7.68$ (t, $1 \mathrm{H} J=7.5 \mathrm{~Hz}, \mathrm{C} 4 H \mathrm{pic})$, $7.06(\mathrm{~d}, 1 \mathrm{H}, J=5.0 \mathrm{~Hz}, \mathrm{C} 6 \mathrm{H} \mathrm{pic}), 6.95(\mathrm{t}, 1 \mathrm{H} J=7.5 \mathrm{~Hz}$, C5Hpic). ${ }^{1} \mathrm{H}$ NMR $\left(\mathrm{CD}_{3} \mathrm{CN}\right): 8.53\left(\mathrm{~d}, 2 \mathrm{H}, J=5.4 \mathrm{~Hz}, \mathrm{C} 6 H / \mathrm{C}^{\prime \prime} H\right)$, $8.44\left(\mathrm{~s}, 2 \mathrm{H}, \mathrm{C}^{\prime} H / \mathrm{C}^{\prime} H\right), 8.35$ (d, $\left.2 \mathrm{H}, J=8.0 \mathrm{~Hz}, \mathrm{C} 3 H / \mathrm{C} 3^{\prime \prime} H\right)$, 7.95-7.87 (m, 3H, C4H/C4" H/ C3H pic), 7.55 (t, $2 \mathrm{H}, J=6.5 \mathrm{~Hz}$, C5H/C5"H), 7.50 (t, 1H, $J=7.5 \mathrm{~Hz}, \mathrm{C} 4 H$ pic), $6.79(\mathrm{t}, 1 \mathrm{H}, J=$ $7.0 \mathrm{~Hz}, \mathrm{C} 5 \mathrm{H}$ pic), 6.76 (d, $1 \mathrm{H}, J=4.7 \mathrm{~Hz}, \mathrm{C} 6 \mathrm{H}$ pic). ${ }^{13} \mathrm{C} \mathrm{NMR}$ $\left(\left(\mathrm{CD}_{3}\right)_{2} \mathrm{CO} / \mathrm{D}_{2} \mathrm{O}(6: 1)\right.$; the shifts were referenced to the residual peak of the $\left(\mathrm{CD}_{3}\right)_{2} \mathrm{CO}$ at $\left.\delta=29.84\right): 159.5\left(C 2^{\prime} / C 6^{\prime}\right), 158.1(C 2 /$ $\left.C 2^{\prime \prime}\right), 152.0\left(C 6 \mathrm{H} / C 6^{\prime \prime} \mathrm{H}\right), 151.5$ (C6H pic), $137.1\left(C 4 \mathrm{H} / C 4^{\prime \prime} \mathrm{H}\right)$, $136.6\left(C 4^{\prime}\right), 136.1$ (C4H pic), $128.4\left(C 5 \mathrm{H} / C 5^{\prime \prime} \mathrm{H}\right), 128.1(C 5 \mathrm{H}$ pic), 127.1 (C3H pic), $123.9\left(C 3 \mathrm{H} / C 3^{\prime \prime} \mathrm{H}\right), 122.6\left(C 3^{\prime} \mathrm{H} / C 5^{\prime} \mathrm{H}\right)$. Selected IR (KBr, cm ${ }^{-1}$ ): $\nu_{\text {terpy }} 2918(\mathrm{~m}), 2850(\mathrm{~m}), 1596$ (s), 1473 (w), 1423 (w), 1112 (s), 794 (m), 566 (w); $\nu_{\text {asym(coo) }} 1630$ (vs); $\nu_{\text {sym(COO) }} 1343$ (s). UV/visible spectrum $\left(\mathrm{CH}_{3} \mathrm{CN} ; \lambda_{\max }, \mathrm{nm}\right.$ ( $\left.\varepsilon, \mathrm{M}^{-1} \mathrm{~cm}^{-1}\right)$ ): 240 (51 690), 280 (37 157), 315 (49133), 369 (13 253), 510 (12 480).

\section{Kinetic analysis}

The kinetics of the substitution reactions of complexes $\mathbf{1}$ and $\mathbf{2}$ with L-His were studied UV-Vis spectrophotometrically. All kinetic measurements were performed under pseudo-firstorder conditions (i.e., the concentration of the nucleophile was at least 10 -fold greater than that of the complex). The reactions were initiated by mixing a solution of each complex $(0.3 \mathrm{~mL}$, $1.00 \mathrm{mM}$ ) with $2.7 \mathrm{~mL}$ of a thermally equilibrated nucleophile solution $(4.45 \mathrm{mM})$ in a UV-Vis cuvette and the reactions were followed for at least 8 half-lives. The observed pseudo-firstorder rate constants, $k_{\text {obsd }}$, represent an average value of two to three independent kinetic runs for each employed experimental condition. The reactions were studied at three different temperatures (288, 298 and $310 \mathrm{~K}$ ) in $25 \mathrm{mM}$ Hepes buffer containing $30 \mathrm{mM} \mathrm{NaCl}$ at $\mathrm{pH}$ 7.40. The second-order rate constants $k_{2}$ for the substitution reactions with L-His were obtained directly from the slopes of $k_{\text {obsd }}$ plotted versus the concentration of the nucleophile. All kinetic data were computer-fitted to the appropriate equation using the programs Microsoft Excel 2007 and Origin 8. 


\section{Quantum chemical methods}

B3LYP/LANL2DZp hybrid density functional calculations, i.e., with pseudo-potentials on the heavy elements and the valence basis set augmented with polarization functions, were performed. ${ }^{73}$ All the resulting structures were characterized as minima by computation of vibrational frequencies (NImag: 0). The relative energies were corrected for zero point vibrational energies (ZPE) throughout. The GAUSSIAN 09 suite of programs was used. ${ }^{74}$ The influence of the bulk solvent was evaluated via calculations using the CPCM formalism (as implemented in GAUSSIAN 09) for water as the solvent, i.e., in the case of energy single points B3LYP(CPCM)/LANL2DZp// B3LYP/LANL2DZp + ZPE(B3LYP/LANL2DZp) or structural optimizations B3LYP(CPCM)/LANL2DZp + ZPE(B3LYP(CPCM)/ LANL2DZp). ${ }^{75}$

\section{Lipophilicity assay}

$\log P_{\mathrm{o} / \mathrm{w}}$ is the partition coefficient between octanol and water which is determined using the flask-shaking method. ${ }^{76}$ An aliquot of a stock solution of complexes 1 and 2 in $100 \mathrm{mM}$ aqueous $\mathrm{NaCl}(0.9 \% \mathrm{w} / \mathrm{v}$ to prevent aqueous interactions and remain saturated with octanol) was added to an equal volume of octanol (saturated with $0.9 \% \mathrm{NaCl} \mathrm{w} / \mathrm{v}$ ). The mixture was shaken overnight at $60 \mathrm{rpm}$ at $298 \mathrm{~K}$ to allow partitioning. After standing, the aqueous layer was carefully separated from the octanol layer for ruthenium analysis. The ruthenium concentration in the aqueous phase was determined using UV-Vis spectrophotometry and used to calculate the $[\mathrm{Ru}]_{\mathrm{o}} /[\mathrm{Ru}]_{\mathrm{w}}$ ratio.

\section{DNA-binding studies}

Absorption spectroscopic studies. The interaction of complexes 1 and 2 with CT DNA has been studied using UV spectroscopy in order to investigate the possible binding modes to CT DNA and to calculate the binding constants $\left(K_{\mathrm{b}}\right)$. The DNA-binding experiments were performed at $37{ }^{\circ} \mathrm{C}$. A buffer (10 mM tris(hydroxymethyl)aminomethane (Tris)- $\mathrm{HCl}$, $150 \mathrm{mM} \mathrm{NaCl}, \mathrm{pH}=7.4$ ) was used for the absorption measurements. A series of complex-DNA solutions were prepared by mixing complex solutions of a fixed concentration $(12.5 \mu \mathrm{M})$ with increments of the DNA stock solution (2.56 mM).

Fluorescence quenching measurements. The binding interaction of the complexes with DNA was also studied by fluorescence spectroscopy. The fluorescence intensities were measured with the excitation wavelength set at $527 \mathrm{~nm}$ and the fluorescence emission set at $612 \mathrm{~nm}$. The excitation and emission slit widths (each $10 \mathrm{~nm}$ ) and the scan rate were kept constant for all the experiments. Stock solutions of DNA $(2.0 \mathrm{mM})$ and complexes $(0.1 \mathrm{mM})$ were prepared in a $10 \mathrm{mM}$ Tris-HCl buffer solution ( $\mathrm{pH}=7.4,150 \mathrm{mM} \mathrm{NaCl}$ ). A series of complex-DNA solutions was prepared by mixing DNA solutions with different concentrations of the complexes. For fluorescence determination, the final DNA concentration was $80.0 \mu \mathrm{M}$, and the complex concentrations varied from $8.0 \mu \mathrm{M}$ to $80.0 \mu \mathrm{M}$. Before the measurements, the system was shaken and incubated at room temperature for $5 \mathrm{~min}$. The emission was recorded at 550-750 $\mathrm{nm}$.

Viscosity measurements. The viscosity of a DNA solution was measured in the presence of increasing amounts of complexes 1 and 2. The flow time was measured with a digital stopwatch, each sample was measured three times, and then the average flow time was calculated. The data were presented as $\left(\eta / \eta_{0}\right)^{1 / 3}$ against $r$, where $\eta$ is the viscosity of DNA in the presence of the complex and $\eta_{0}$ is the viscosity of DNA alone in the buffer solution. The viscosity values were calculated from the observed flow time of the DNA-containing solutions $(t)$ corrected for the flow time of the buffer alone $\left(t_{0}\right), \eta=\left(t-t_{0}\right) / t_{0}$.

\section{Cell studies}

Cell culture. Three different tumor cell lines were the subjects of this study: A549 (human lung carcinoma cell line), HCT116 (human colon carcinoma cell line), and CT26 (mouse colon carcinoma cell line). These cells were purchased from the American Type Culture Collection (ATCC, Manassas, VA, USA). The cells were cultured in Dulbecco's Modified Eagle Medium (DMEM) supplemented with 10-15\% fetal bovine serum (FBS), $100 \mathrm{U} \mathrm{mL}^{-1}$ penicillin and $100 \mathrm{mg} \mathrm{mL}^{-1}$ streptomycin. All cell lines were kept in a $\mathrm{CO}_{2}$ incubator with $5 \% \mathrm{CO}_{2}$ at $37^{\circ} \mathrm{C}$ under a humidified atmosphere. The cells from a confluent monolayer were removed from the flasks by a trypsinEDTA solution and seeded in multi-well culture plates.

Cytotoxicity assay (MTT test). The cytotoxic activity of complexes 1, 2, 3, 4 and P2 were screened against all cell lines using the MTT [3-(4,5-dimethylthiazol-2-yl)-2,5-diphenyltetrazolium bromide] assay, a colorimetric determination of cell viability during in vitro treatment with a drug. The assay, developed for the initial stage of drug screening, measures the amount of MTT reduction by mitochondrial dehydrogenase and assumes that cell viability (corresponding to the reduced activity) is proportional to the production of purple formazan, which is measured spectrophotometrically. The cells were harvested from the culture during the exponential growth phase and seeded into 96-well culture plates at $5 \times 10^{4}$ cells per $\mathrm{mL}$ in fresh medium, $100 \mu \mathrm{L}$ per well. After $24 \mathrm{~h}$, the cells were treated with selected concentrations of the complexes for 3 days. Control wells were prepared by the addition of culture medium alone, which were used as blanks. After incubation, the drug-containing medium was discarded and replaced with serum-free medium containing 15\% MTT (5 mg $\left.\mathrm{mL}^{-1}\right)$ dye. After an additional $4 \mathrm{~h}$ of incubation at $37{ }^{\circ} \mathrm{C}$ in the $5 \% \mathrm{CO}_{2}$ incubator, the medium with MTT was removed and DMSO $(150 \mu \mathrm{L})$ with glycine buffer $(20 \mu \mathrm{L})$ was added to dissolve the blue formazan crystals. The plates were shaken for $10 \mathrm{~min}$. The optical density of each well was determined at $570 \mathrm{~nm}$ using a Zenyth 3100 multimode microplate detector. Each experiment was repeated at least three times to obtain mean values. The percentage of cytotoxicity was calculated using the formula: $\%$ of viable cells $=((\mathrm{TS}-\mathrm{BG} 0)-\mathrm{E} /(\mathrm{TS}-\mathrm{BG0}) \times 100)$, where BG0 is for the background of the medium alone, TS is for the total viability/spontaneous death of untreated target cells, and $\mathrm{E}$ is for the experimental well. The $\mathrm{IC}_{50}$ values were 
determined by plotting the percentage viability versus concentration on a logarithmic graph and reading off the concentration at which $50 \%$ of the cells remained viable relative to the control.

\section{Conclusion}

In a previous study, the syntheses of three cationic complexes with terpyridine of the general formula $[\mathrm{Ru}(\mathrm{Cl}-\mathrm{tpy})(\mathrm{chel}) \mathrm{Cl}][\mathrm{Cl}]$ were reported, and their stability and behavior in aqueous solution, as well as their interaction with different biomacromolecules (such as DNA model bases, amino acids, etc.), were thoroughly investigated. ${ }^{30}$ These polypyridyl complexes undergo release of the chlorido ligand forming the corresponding $\left[\mathrm{Ru}\left(\mathrm{Cl} \text {-tpy) }(\mathrm{chel})\left(\mathrm{H}_{2} \mathrm{O}\right)\right]^{2+}\right.$ species. The rate of hydrolysis was found to depend markedly on the nature of the chelating ligand (minutes for en and dach, hours for bpy), but its extent was similar in all cases, with a $c a$. $1: 9$ ratio between intact and aquated species at equilibrium. On the other hand, the neutral complex $[\mathrm{Ru}(\mathrm{Cl}$-tpy)(pic)Cl] (4) reported herein has poor solubility in aqueous solution and higher stability since no release of the $\mathrm{Cl}^{-}$ligand was detected after several hours of observation.

This study provides information on the mechanism of substitution of ruthenium(II) terpyridine complexes with the amino acid L-His. The kinetic data for the reactions of two cationic complexes $[\mathrm{Ru}(\mathrm{Cl}$-tpy)(en)Cl][Cl] (1) and $[\mathrm{Ru}(\mathrm{Cl}$-tpy) (dach)Cl][Cl] (2) with L-His clearly showed that the rate of the reaction depends on the nature of the chelating ligand: the en complex 1 reacts $c a$. 2 times faster than the dach complex 2 . In addition, NMR data indicated that in the early stage, L-His binds to complexes 1 and 2 through the N3 atom, while in the later stage through the thermodynamically more stable N1 atom. The inner molecular rearrangement from N3-coordinated $\mathrm{L}$-His to the $\mathrm{N} 1$ bound isomer observable in the NMR data can be corroborated by DFT calculations favoring $\mathrm{N} 1$ coordination by nearly $4 \mathrm{kcal} \mathrm{mol}^{-1}$.

UV-Vis spectroscopy studies, DNA viscosity measurements and competitive binding studies with EB revealed the ability of the complexes to bind to CT DNA covalently through N7 of guanine residues and non-covalently through intercalation. The cytotoxicities of the five ruthenium(II) polypyridyl complexes $[\mathrm{Ru}(\mathrm{Cl}$-tpy)(en)Cl][Cl] (1), [Ru(Cl-tpy)(dach)Cl][Cl] (2), $[\mathrm{Ru}(\mathrm{Cl}$-tpy)(bpy)Cl][Cl] (3), [Ru(Cl-tpy)(pic)Cl] (4) and $[\mathrm{Ru}($ tpy) $\mathrm{Cl}_{3}$ ] (P2) was investigated against three different tumor cell lines, A549, HCT116 and CT26, by the MTT assay. The $\mathrm{IC}_{50}$ values showed that complexes $\mathbf{1}$ and $\mathbf{2}$ were moderately cytotoxic, while complexes $\mathbf{3}, \mathbf{4}$ and $\mathbf{P 2}$ were devoid of any significant cytotoxicity. In substantial agreement with the results obtained by Sadler and Alessio for organometallic half sandwich compounds and $\mathrm{Ru}(\mathrm{II})-[9]$ aneS complexes, respectively, the present results clearly confirmed that the relatively rapid availability of one coordination position on the $\mathrm{Ru}$ center is apparently an essential requirement for observing anticancer activity. In addition, ethylenediamine is instrumental for the cytotoxic activity. This study provides additional confirmation that ruthenium complexes could indeed have multiple targets and mechanisms of action. Interactions of these ruthenium polypyridyl compounds with transport proteins, such as albumin and transferrin, are currently underway, and the results will be reported elsewhere. Therefore, the investigation in this direction is of particular importance for the future development of new ruthenium anticancer drugs with reduced side-effects, and more work is required for gaining a better understanding.

\section{Acknowledgements}

The authors gratefully acknowledge financial support from the Ministry of Education, Science and Technological Development of the Republic of Serbia, Project No. 172011. The authors gratefully acknowledge the Regionales Rechenzentrum Erlangen (RRZE) for a generous allotment of computer time and we would like to thank Prof. Tim Clark for hosting this work at the CCC.

\section{References}

1 P. E. N. Barry and J. P. Sadler, Chem. Commun., 2013, 49, 5106-5131.

2 M. Markman, Expert. Opin. Drug. Saf., 2003, 7, 597-607.

3 P. C. Bruijnincx and P. J. Sadler, J. Curr. Opin. Chem. Biol., 2008, 12, 197-206.

4 V. M. Motswainyana and P. A. Ajibade, Adv. Chem., 2015, 1-21.

5 E. Alessio, Bioinorganic Medicinal Chemistry, Wiley VCH Verlag \& Co. KGaA, Weinheim, Germany, 2011.

6 I. Bratsos, S. Jedner, T. Gianferrara and E. Alessio, Chimia, 2007, 61, 692-697.

7 R. Trondl, P. Heffeter, C. R. Kowol, M. A. Jakupec, W. Berger and B. K. Keppler, Chem. Sci., 2014, 5, 29252932.

8 C. G. Hartinger, S. Zorbas-Seifried, M. A. Jakupec, B. Kynast, H. Zorbas and B. K. Keppler, J. Inorg. Biochem., 2006, 100, 891-904.

9 W. H. Ang and P. J. Dyson, Eur. J. Inorg. Chem., 2006, 20, 4003-4018.

10 P. J. Dyson, Chimia, 2007, 61, 698-703.

11 P. J. Dyson and G. Sava, Dalton Trans., 2006, 1929-1933.

12 C. S. Allardayce, A. Dorcier, C. Scolaro and P. J. Dyson, Appl. Organomet. Chem., 2005, 19, 1-10.

13 J. M. Rademaker-Lakhai, D. van den Bongard, D. Pluim, J. H. Beijnen and J. H. Schellens, Clin. Cancer Res., 2004, 10, 3717-3727.

14 C. G. Hartinger, M. A. Jakupec, S. Zorbas-Seifried, M. Groessl, A. Egger, W. Berger, H. Zorbas, P. J. Dyson and B. K. Keppler, Chem. Biodiversity, 2008, 5, 2140-2155.

15 P. G. Dyson and G. Sava, Dalton Trans., 2006, 1929-1933.

16 A. Bergamo and G. Sava, Dalton Trans., 2007, 1267-1272. 
17 Y. K. Yan, M. Melchart, A. Habtemariam and P. J. Sadler, Chem. Commun., 2005, 4764-4776.

18 G. Gasser, I. Ott and N. Metzler-Nolte, J. Med. Chem., 2011, 54, 3-25.

19 G. Süss-Fink, Dalton Trans., 2010, 39, 1673-1688.

20 R. E. Aird, J. Cummings, A. A. Ritchie, M. Muir, R. E. Morris, H. Chen, P. J. Sadler and D. I. Jodrell, Br. J. Cancer, 2002, 86, 1652-1657.

21 A. F. A. Peacock and P. J. Sadler, Chem. - Asian J., 2008, 3, 1890-1899.

22 H. Chen, J. A. Parkinson, S. Parsons, R. A. Coxall, R. O. Gould and P. J. Sadler, J. Am. Chem. Soc., 2002, 124, 3064-3082.

23 N. Grover, N. Gupta and H. H. Thorp, J. Am. Chem. Soc., 1992, 114, 3390-3393.

24 G. A. Neyhart, N. Grover, S. R. Smith, W. A. Kalsbeck, T. A. Fairley, M. Cory and H. Holden Thorp, J. Am. Chem. Soc., 1993, 115, 4423-4428.

25 Y. Mulyana, G. Collins and R. Keene, J. Inclusion Phenom. Macrocyclic Chem., 2011, 71, 371-379.

26 C. C. Cheng, W. L. Lee, J. G. Su and C. L. Liu, J. Chin. Chem. Soc., 2000, 47, 213-220.

27 E. Corral, A. C. G. Hotze, A. Magistrato and J. Reedijk, Inorg. Chem., 2007, 46, 6715-6722.

28 E. Corral, A. C. G. Hotze, H. Den Dulk, A. Leczkowska, A. Rodger, M. J. Hannon and J. Reedijk, J. Biol. Inorg. Chem., 2009, 14, 439-448.

29 O. Novakova, J. Kasparkova, O. Vrana, P. M. van Vliet, J. Reedijk and V. Brabec, Biochemistry, 1995, 34, 1236912378.

30 A. Rilak, I. Bratsos, E. Zangrando, J. Kljun, I. Turel, Ž. D. Bugarčić and E. Alessio, Inorg. Chem., 2014, 53, 61136126.

31 F. Piccioli, S. Sabatini, L. Messori, P. Orioli, C. G. Hartinger and B. K. Keppler, J. Inorg. Biochem., 2004, 98, 11351142.

32 W. Hu, Q. Luo, X. Ma, K. Wu, J. Liu, Y. Chen, S. Xiong, J. Wang, P. J. Sadler and F. Wang, Chem. - Eur. J., 2009, 15, 6586-6594.

33 A. Levina, J. B. Aitken, Y. Y. Gwee, Z. J. Lim, M. Liu, A. M. Singharay, P. F. Wong and P. A. Lay, Chem. - Eur. J., 2013, 19, 3609-3619.

34 W. Guo, W. Zheng, Q. Luo, X. Li, Y. Zhao, S. Xiong and F. Wang, Inorg. Chem., 2013, 52, 5328-5338.

35 Ž. D. Bugarčić, S. T. Nandibewoor, M. S. A. Hamza, F. Heinemann and R. van Eldik, Dalton Trans., 2006, 29842990.

36 W. Kaim and B. Schwederski, Bioinorganic Chemistry: Inorganic Elements in the Chemistry of Life, John Wiley \& Sons, New York, 1st edn, 1994, pp. 16-35, 106-123.

37 D. Chatterjee, A. Sengupta and A. Mitra, Polyhedron, 2007, 26, 178-183.

38 M. N. Patel, D. S. Gandhi, P. A. Parmar and H. N. Joshi, J. Coord. Chem., 2012, 65, 1926-1936.

39 A. Dovletoglou, S. A. Adeyemi and T. J. Meyer, Inorg. Chem., 1996, 35, 4120-4127.
40 K. Spiewak and M. Brindell, J. Biol. Inorg. Chem., 2015, 20, 695-703.

41 F. Wang, J. Bella, J. A. Parkinson and P. J. Sadler, J. Biol. Inorg. Chem., 2005, 10, 147-155.

42 D. Das, A. Dutta and P. Mondal, RSC Adv., 2014, 4, 6054860556.

43 A. Rilak, B. Petrović, S. Grgurić-Šipka, Ž. Tešić and Ž. Bugarčić, Polyhedron, 2011, 30, 2339-2344.

44 A. Rilak, I. Bratsos, E. Zangrando, J. Kljun, I. Turel, Ž. D. Bugarčić and E. Alessio, Dalton Trans., 2012, 41, 11608-11618.

45 A. Rilak, R. Pushta and Ž. D. Bugarčić, Polyhedron, 2015, 91, 73-83.

46 R. L. S. R. Santos, R. van Eldik and D. de Oliveira Silva, Inorg. Chem., 2015, 51, 6615-6625.

47 D. R. Lide, Handbook of Chemistry and Physics, CRC Press Taylor, Francis, Boca Raton, FL, 2010.

48 N. Summa, W. Schiessl, R. Puchta, N. van Eikema Hommes and R. van Eldik, Inorg. Chem., 2006, 45, 2948-2959.

$49 \mathrm{~J}$. A. Joule and K. Mills, in Heterocyclic Chemistry at a Glance, J. Wiley and Sons, Ltd, United Kingdom, 2nd edn, 2013, p. 10.

50 G. Enos, A. Mambanda and D. Jaganyi, J. Coord. Chem., 2013, 66, 4280-4291.

51 (a) M. Klisch, P. Richter, R. Puchta, D.-P. Häder and W. Bauer, Helv. Chim. Acta, 2007, 90, 488-511; (b) P. Skurski, M. Gutowski, R. Barrios and J. Simons, Chem. Phys. Lett., 2001, 337, 143-150.

52 W. S. Sheldrick and R. Exner, Inorg. Chim. Acta, 1992, 195, 1-9.

53 W. S. Sheldrick and S. Heeb, J. Organomet. Chem., 1989, 377, 357-366.

54 I. V. Rogachevsky and V. I. Baranovski, Spectrochim Acta, Part A, 2000, 56, 2699-2705.

55 L. Fetzer, B. Boff, M. Ali, X. Meng, J. P. Collin, C. Sirlin, C. Gaiddon and M. Pfeffer, Dalton Trans., 2011, 40, 88698878.

56 C. X. Zhang and S. J. Lippard, Curr. Opin. Chem. Biol., 2003, 7, 481-489.

57 J. Liu, W. Zheng, S. Shi, C. Tan, J. Chen, K. Zheng and L. Ji, J. Inorg. Biochem., 2008, 102, 193-202.

58 V. Brabec, Prog. Nucleic Acid Res. Mol. Biol., 2002, 71, 1-68.

59 V. Brabec and O. Novakova, Drug Resist. Updates, 2006, 9, 111-122.

60 O. Novakova, H. Chen, O. Vrana, A. Rodger, P. J. Sadler and V. Brabec, Biochemistry, 2003, 42, 11544-11554.

61 H. Chen, J. A. Parkinson, R. E. Morris and P. J. Sadler, J. Am. Chem. Soc., 2003, 125, 173-186.

62 F. Caruso, E. Monti, J. Matthews, M. Rossi, M. B. Gariboldi, C. Pettinari, R. Pettinari and F. Marchetti, Inorg. Chem., 2014, 53, 3668-3677.

63 A. Tarushi, E. Polatoglou, J. Kljun, I. Turel, G. Psomas and D. P. Kessissoglou, Dalton Trans., 2011, 40, 9461-9473.

64 A. Tarushi, K. Lafazanis, J. Kljun, I. Turel, A. A. Pantazaki, G. Psomas and D. P. Kessissoglou, J. Inorg. Biochem., 2013, 121, 53-65. 
65 A. Dimitrakopoulou, C. Dendrinou-Samara, A. A. Pantazaki, M. Alexlou, E. Nordlander and D. P. Kessissoglou, J. Inorg. Biochem., 2008, 102, 618-628.

66 C. V. Kumar, J. K. Barton and N. J. Turro, J. Am. Chem. Soc., 1985, 107, 5518-5523.

67 D. D. Li, J. L. Tian, W. Gu, X. Liu and S. P. Yan, J. Inorg. Biochem., 2010, 104, 171-179.

68 M. Jiang, Y. Li, Z. Wu, Z. Liu and C. Yan, J. Inorg. Biochem., 2009, 103, 833-844.

69 I. Bratsos, S. Jedner, A. Bergamo, G. Sava, T. Gianferrara, E. Zangrando and E. Alessio, J. Inorg. Biochem., 2008, 102, 1120-1133.

70 I. Bratsos, E. Mitri, F. Ravalico, E. Zangrando, T. Gianferrara, A. Bergamo and E. Alessio, Dalton Trans., 2012, 41, 7358-7371.

71 B. P. Sullivan, J. M. Calvert and T. J. Meyer, Inorg. Chem., 1980, 19, 1404-1407.

72 K. A. Meadows, F. Liu, J. Sou, B. P. Hudson and D. R. McMillin, Inorg. Chem., 1993, 32, 2919-2923.

73 (a) A. D. Becke, J. Phys. Chem., 1993, 97, 5648-5652; (b) C. Lee, W. Yang and R. G. Parr, Phys. Rev. B: Condens. Matter, 1988, 37, 785-789; (c) P. J. Stephens, F. J. Devlin, C. F. Chabalowski and M. J. Frisch, J. Phys. Chem., 1994, 98, 11623-11627; (d) T. H. Dunning Jr. and P. J. Hay, Mod. Theor. Chem., 1976, 3, 1-28; (e) P. J. Hay and W. R. Wadt, J. Chem. Phys., 1985, 82, 270-283; $(f)$ P. J. Hay and W. R. Wadt, J. Chem. Phys., 1985, 82, 284-298; (g) P. J. Hay and W. R. Wadt, J. Chem. Phys., 1985, 82, 299-310; (h) S. Huzinaga, in Gaussian Basis Sets for Molecular Calculations, Elsevier, Amsterdam, 1984; (i) The performance of the computational level employed in this study is well documented for different systems, see for example: (j) R. Puchta, R. Meier, N. J. R. van Eikema Hommes and R. van Eldik, Eur. J. Inorg. Chem., 2006, 4063-4067; (k) A. Scheurer, H. Maid, F. Hampel, R. W. Saalfrank, L. Toupet, P. Mosset, R. Puchta and N. J. R. van Eikema Hommes, Eur. J. Org. Chem., 2005, 2566-2574; (l) P. Illner,
A. Zahl, R. Puchta, N. van Eikema Hommes, P. Wasserscheid and R. van Eldik, J. Organomet. Chem., 2005, 690, 3567-3576; ( $m$ ) M. Galle, R. Puchta, N. J. R. van Eikema Hommes and R. van Eldik, Phys. Chem., 2006, 220, 511-523; (n) R. Puchta, L. Dahlenburg and T. Clark, Chem. - Eur. J., 2008, 14, 8898-8903; (o) P. Illner, S. Begel, S. Kern, R. Puchta and R. van Eldik, Inorg. Chem., 2009, 48, 588-597; ( $p$ ) B. M. Alzoubi, F. Vidali, R. Puchta, C. DückerBenfer, A. Felluga, L. Randaccio, G. Tauzher and R. van Eldik, Dalton Trans., 2009, 2392-2399; (q) T. Soldatović, M. Shoukry, R. Puchta, Ž. D. Bugarčić and R. van Eldik, Eur. J. Inorg. Chem., 2009, 2261-2270; (r) S. Begel, A. Scheurer and R. Puchta, J. Coord. Chem., 2015, 68, 33743387 and the literature cited therein.

74 M. J. Frisch, G. W. Trucks, H. B. Schlegel, G. E. Scuseria, M. A. Robb, J. R. Cheeseman, G. Scalmani, V. Barone, B. Mennucci, G. A. Petersson, H. Nakatsuji, M. Caricato, X. Li, H. P. Hratchian, A. F. Izmaylov, J. Bloino, G. Zheng, J. L. Sonnenberg, M. Hada, M. Ehara, K. Toyota, R. Fukuda, J. Hasegawa, M. Ishida, T. Nakajima, Y. Honda, O. Kitao, H. Nakai, T. Vreven, J. A. Montgomery Jr., J. E. Peralta, F. Ogliaro, M. Bearpark, J. J. Heyd, E. Brothers, K. N. Kudin, V. N. Staroverov, R. Kobayashi, J. Normand, K. Raghavachari, A. Rendell, J. C. Burant, S. S. Iyengar, J. Tomasi, M. Cossi, N. Rega, J. M. Millam, M. Klene, J. E. Knox, J. B. Cross, V. Bakken, C. Adamo, J. Jaramillo, R. Gomperts, R. E. Stratmann, O. Yazyev, A. J. Austin, R. Cammi, C. Pomelli, J. W. Ochterski, R. L. Martin, K. Morokuma, V. G. Zakrzewski, G. A. Voth, P. Salvador, J. J. Dannenberg, S. Dapprich, A. D. Daniels, O. Farkas, J. B. Foresman, J. V. Ortiz, J. Cioslowski and D. J. Fox, Gaussian, Inc., Wallingford, CT, 2009.

75 (a) V. Barone and M. Cossi, J. Phys. Chem., 1998, 102, 19952001; (b) M. Cossi, G. Scalmani, N. Rega and V. Barone, J. Comput. Chem., 2003, 24, 669-681.

76 C. A. Puckett and J. K. Barton, J. Am. Chem. Soc., 2007, 129, 46-47. 